NBER WORKING PAPER SERIES

\title{
SOVEREIGN RISK, CREDIBILITY AND THE GOLD STANDARD: 1870-1913 VERSUS 1925-31
}

\author{
Maurice Obstfeld \\ Alan M. Taylor \\ Working Paper 9345 \\ http://www.nber.org/papers/w9345 \\ NATIONAL BUREAU OF ECONOMIC RESEARCH \\ 1050 Massachusetts Avenue \\ Cambridge, MA 02138 \\ November 2002
}

This paper is forthcoming in The Economic Journal. For help with data we thank Pranab Bardhan, Luis Bértola, Michael Bordo, Guillermo Bózzoli, Charles Calomiris, Gregory Clark, Niall Ferguson, Albert Fishlow, Stephen Haber, Ian McLean, Lawrence Officer, Sevket Pamuk, Leandro Prados de la Escosura, Jaime Reis, Gail Triner and Tarik Yousef. For outstanding research assistance we thank Miguel Fuentes and David Jacks. We received very helpful comments from participants at the joint Money, Macro and Finance/Understanding the Evolving Macroeconomy conference held at the University ofWarwick in September 2002. All errors are our own. Obstfeld gratefully acknowledges the support of the United States National Science Foundation, through a grant to the National Bureau of Economic Research. Taylor gratefully acknowledges the support of the Chancellor's Fellowship at the University of California, Davis. The views expressed herein are those of the authors and not necessarily those of the National Bureau of Economic Research.

(C) 2002 by Maurice Obstfeld and Alan M. Taylor. All rights reserved. Short sections of text, not to exceed two paragraphs, may be quoted without explicit permission provided that full credit, including $\mathbb{C}$ notice, is given to the source. 
Sovereign Risk, Credibility and the Gold Standard: 1870-1913 versus 1925-31

Maurice Obstfeld and Alan M. Taylor

NBER Working Paper No. 9345

November 2002

JEL No. F2, F33, F36, F41, N10, N20

\begin{abstract}
What determines sovereign risk? We study the London bondmarket from the 1870 s to the 1930s. Our findings support conventional wisdom concerning the low credibility of the interwar gold standard. Before 1914 gold standard adherence effectively signalled credibility and shaved 40 to 60 basis points from country borrowing spreads. In the 1920s, however, simply resuming prewar gold parities was insufficient to secure such benefits. Countries that devalued before resumption were treated favorably, and markets scrutinized other signals. Public debt and British Empire membership were important determinants of spreads after World War One, but not before.
\end{abstract}

\author{
Maurice Obstfeld \\ Department of Economics \\ 549 Evans Hall \\ University of California \\ Berkeley, CA 94720-3880 \\ NBER and CEPR \\ obstfeld@econ.berkeley.edu
}

\author{
Alan M. Taylor \\ Department of Economics \\ University of California \\ One Shields Avenue \\ Davis, CA 95616-8578 \\ and NBER \\ amtaylor@ucdavis.edu
}




\section{Introduction}

Can macroeconomic policymakers enhance credibility, and thus performance, by the adoption of a hard currency peg? The experiment is often attempted. In recent years many countries have tried to end histories of macroeconomic instability through reform programs based on a fixed exchange rate. The variants of fixed exchange rates have ranged from conventional currency pegs to currency boards to currency unions to dollarisation, sometimes accompanied by elaborate institutional engineering meant to enhance credibility with the markets.

Yet the success of these efforts has varied a great deal across countries. In particular, the Argentine peso's diastrous collapse after ten years of parity with the United States dollar illustrates the difficulty nowadays of establishing credibility even through some of the "harder" variants of currency peg. How should we interpret such an outcome? We think that an exploration of a large set of historical episodes could be informative. This paper aims to thow light on the relationship between exchange rate regimes and credibility by closely examining two adjacent but very different historical epochs of widespread exchange rate stabilisation, the classical pre-World War One gold standard period and the years 1925-31 of the interwar gold standard.

It is now widely believed that prior to 1914 , gold standard orthodoxy conferred credibility and was a sine qua non for access to global capital markets on favorable terms. A path-breaking study by Bordo and Rockoff (1996) found that adherence to gold standard rules acted as a "seal of approval" for sovereign debt. Gold standard countries had lower country risk, measured by their bond spreads in London relative to the British consol. By the time the interwar gold standard was reconstituted starting in 1925, however, the underlying political equilibrium in most economies had changed, with more political power in the hands of previously disadvantaged working class parties and a greater awareness of government's role in steering economic outcomes (Polanyi, 1944; Temin, 1989; Eichengreen, 1996). Indeed, divergent interest-group positions on macroeconomic policy were reflected in the high inflation rates rampant in the early 1920s and in the national debates over the appropriate exchange parity-devalued or not—at which to return to gold.

Hard evidence of a new political dynamic might be sought in a changing relationship between country risk and gold after 1925. With the rules of the game in question after World War One, perhaps investors doubted that the mere adoption of a gold standard regime would ensure the repayment of public debts. Consistent with such imperfect credibility, other indicators that could reassure foreign investors about public solvency (such as the debt-GDP ratio) or protection of capi- 
tal (such as membership in the British Empire) might have had a bigger impact on international bond spreads under the reconstituted gold standard than before. Do the data indeed support these conjectures?

There is no uniform and comprehensive study of bond spreads across the pre1914 and interwar gold standards that would allow us definitively to answer such questions. A study of interwar spreads by Bordo, Edelstein, and Rockoff (1999), however, came to a conclusion that was surprising, even by the authors' own admission. ${ }^{1}$ Looking solely at 1920 s bond yields, they found continued evidence that the gold standard remained a seal of approval when a country returned to its prewar exchange parity with gold, lowering bond spreads significantly in that case. Devaluers were not so lucky with their bond spreads: for them, the effect of being on gold was found to be small and statistically insignificant. Such findings seem to challenge the conventional wisdom that the interwar gold standard was a pale and less credible shadow of its predecessor.

These are two pioneering studies, but they are not ideal for comparative work across regimes because of differences in the type of data that each employs. The former study looked at long-term government bonds in the secondary market, and examined their yield to maturity; the latter examined new issues and their yield at the moment of flotation only. The former study therefore had complete time series, whereas the latter had a small sample that was often interrupted by missing data in years when no issues took place - a not uncommon event in the 1920s, and one that raises a potential sample-selection issue (presumably, bonds tend not to be floated when conditions are unfavorable). Finally, the former study examined prices in London, the latter prices in New York, a defensible switch as the hegemonic centre of global capital markets shifted across the Atlantic around this time, and one that allowed the use of Cleona Lewis's (1938) figures on new issues during the 1920s.

To overcome the differences between these two earlier investigations, we compare the determinants of bond spreads in the pre-1914 and interwar years using a consistent set of data for a larger sample of countries from 1870 through 1939. We focus on a sample of more than 20 diverse countries - some within the British Empire, some outside, some in the core and some in the periphery-to see how their country risk evolved. This allows us to focus on the same type of risk measure across both prewar and interwar eras. To isolate the effects of default (as opposed to exchange rate) risk, spreads over London are exclusively for bonds denominated

\footnotetext{
${ }^{1}$ See also Ferguson (2001, p. 333), who suggests that the surprising conclusion of the interwar study throws doubt on the findings in the original Bordo-Rockoff study of pre-1914 yields. However, the two studies use very different sources for their yield data, as we explain in a moment.
} 
in gold or in sterling. Most of our yield-to-maturity data come from the Global Financial Data (GFD) source and pertain to bonds traded in London. When GFD did not report appropriate data for gold or sterling-indexed bonds, however, we collected it ourselves from contemporary journalistic sources, in a few cases resorting to yield quotations from the New York market.

Figure 1 offers an overview of our yield data over the full period 1870-1939. The mean bond spreads over London for two subsamples (the Core and Empire subset and the Periphery Nonempire subsets) are presented in the top and bottom charts respectively, and each is surrounded by a measure of dispersion, a band equal to plus or minus two standard deviations. ${ }^{2}$ The units are percentage points and the scales are deliberately the same on the two charts.

The differences between the two subsamples are very striking: the core had much smaller country risk than the periphery, as expected. Core and empire countries usually had interest rates within one or two percentage points of Britain's, at least from 1880 to 1930 . The periphery could have spreads as large as five, ten, or even twenty percentage points, the latter spread usually tantamount to being in default.

The figures also show some similarities, once we normalise for this scale difference. Both core and periphery experienced a convergence in bond spreads up to 1914. For both country groupings we observe good deal of volatility in the interwar years, when spreads widened, but there appears to have been some convergence during Britain's brief interwar return to gold, 1925-31. We seek to understand the gold standard's role in these two convergence episodes.

Our empirical analysis allows public indebtedness to play a role in determining borrowing spreads. Macroeconomic variables correlated with gold-standard adherence, such as public debt, might be responsible for the apparent pre-1914 benefits of going on gold, or might mask such benefits after the World War One. Before the war, countries on gold may have had more disciplined fiscal policies, lower public debt, and hence more favorable treatment by the bond markets. On the other hand, countries that inflated away their public debts in the early or mid1920s would have been unlikely to rejoin gold at prewar parity, making high public debts and a return to gold at par positively correlated variables. In these circumstances, one major concern is that failing to control for public debt could lead us to

\footnotetext{
${ }^{2}$ The core countries are Australia, Belgium, Canada, Denmark, France, Germany, New Zealand, Norway, Sweden, and the United States. The empire countries are Australia, Canada, India, New Zealand, and South Africa. The periphery nonempire countries are Argentina, Austria (or AustriaHungary), Brazil, Chile, Finland, Greece, Hungary, Italy, Japan, Mexico, Portugal, Spain, Turkey (or the Ottoman Empire), and Uruguay.
} 
Figure 1: London Bond Spreads, Core and Periphery, 1870-1940
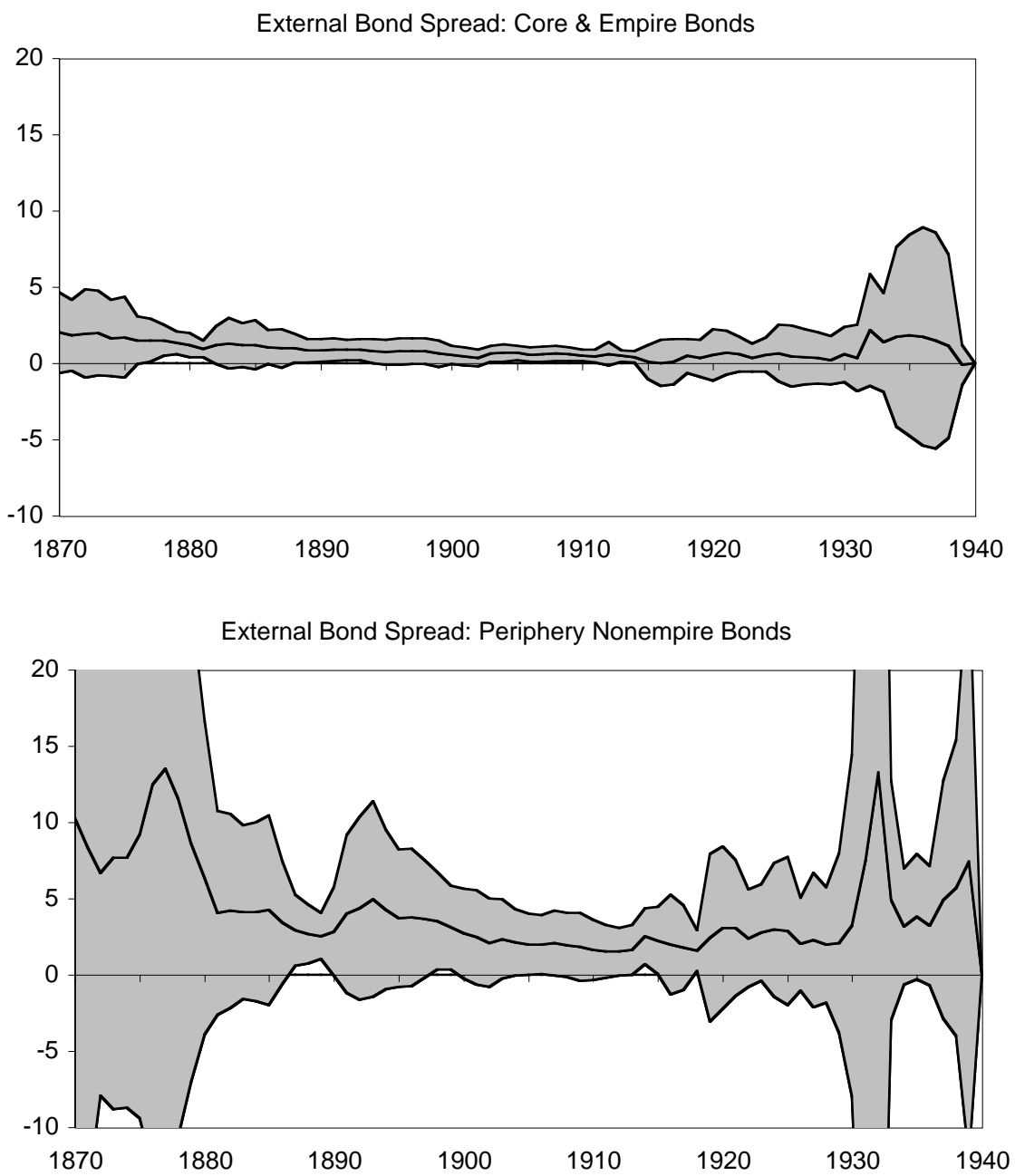

Notes: See text and appendix. Source: Global Financial Data and other sources. 
overestimate the prewar benefit of gold standard adherence and underestimate the postwar benefit of returning to gold at the prewar exchange rate. A contribution of the paper is its collection and use of historical series on the public debts of a large number of borrowing countries. ${ }^{3,4}$

This paper's findings reinstate conventional wisdom concerning the low credibility of the interwar gold standard. We confirm the Bordo-Rockoff (1996) findings on the pre-war gold standard, notwithstanding a larger country sample and the inclusion of a wider set of macro-fundamental determinants of spread. Before the First World War, gold standard adherence was an effective credibility signal that shaved about 40 to 60 basis points from a country's external public borrowing cost. The interwar results below, however, suggest that in the 1920s, returning to gold at prewar parity no longer was enough to soothe international investors. After World War One, there was no significant "good housekeeping" effect of returning to gold at prewar parity. At best, it was the countries returning to gold at depreciated levels that gained; and they gained somewhat less than had prewar gold adherents. Moreover, public debt and Empire membership were important determinants of borrowing spreads after World War One, though not before.

\footnotetext{
${ }^{3}$ Bordo and Rockoff (1996) examined the effect on borrowing spreads of the public deficit relative to GDP, a flow variable, but found it to be statistically insignificant. Our experiments with the deficit variable led to the same negative conclusion. If we wish to assess solvency, however, the stock variable, public debt, seems preferable. Based on a specification that includes public debt, Flandreau et al. (1998) find prewar spread effects of gold-standard adherence similar in size to those reported by Bordo and Rockoff (about 35-55 basis points). We discuss the relation between our results and those of Flandreau et al. below.

${ }^{4}$ The discussion of omitted fiscal variables points to a deeper identification problem in any attempt to pinpoint a "pure" yield effect of gold standard adherence. Countries' decisions over the monetary regime are in most cases endogenously determined, and without controlling for a broad range of economic and political variables, one cannot know whether bond spreads are being driven by gold adherence per se or by the domestic economic circumstances that facilitate adherence or force suspension. We therefore urge extreme caution in the interpretation of our estimated spread "effects" of the gold standard. We can legitimately infer from them, not a gold impact that is independent of other economic factors, but merely a partially unconditional average benefit accruing to countries in a position to adopt the gold standard. During both of the eras we study countries able to adopt gold by and large did so, and we believe that our results do provide a valid approach to understanding how the credibility of gold commitments changed after the First World War. In our empirical examination of the interwar period below, we attempt to control in a crude way for the global disruptions forcing gold standard departures starting in 1929. We hope to address explicitly the regime selection problem in future work, although analysis is complicated by the very diverse scenarios through which various countries have adopted or left the gold standard at different times. Meissner (2002) models empirically the spread of the prewar gold standard.
} 


\section{Five suggestive cases}

Case studies are suggestive but not definitive; we present five for purposes of illustration. Ultimately, careful examination of a broader range of cases would be a useful complement to the more aggregative econometric analysis that we carry out in the next section.

In the United States the Resumption Act came into force in January 1875. The Act legislated a return to a unified gold-backed currency on January 1, 1879. To assess the effect of gold standard adherence on United States government bond spreads, we must account for the fact that the return to gold was anticipated well in advance. One way to do so is to track simultaneously the exchange rate. In Figure 2 we show the paths over time of the price of gold in terms of the floating paper greenbacks issued to finance the Civil War, as well as of the relative yield on gold bonds - specifically, Macaulay's (1938, p. A218) gold railroad bondsrelative to the London consol yield. The announcement that greenbacks would be redeemed at par nearly four years later obviously was not credible early in 1875 . Rather than falling, the greenback price of gold initially rose. Only later in that year did the greenback begin its appreciation toward par. ${ }^{5}$ The concomitant decline in the bond spread is impressive-around 200 basis points.

Argentina returned to the gold standard on October 31, 1899, nearly a decade after abandoning gold in the Baring Crisis. Starting in 1891, the country embarked upon a deflationary policy so as to be able to resume gold convertibility at an unchanged parity, even though the currency utimately was pegged at a devalued rate (see della Paolera and Taylor, 2001). Figure 3 shows how both the exchange rate and the borrowing spread over London behaved: both moved strongly together over the 1890s, suggesting that expectations of resumption and borrowing costs were indeed strongly interrelated. When Julio Roca, a strong advocate of the gold standard, was re-elected to the presidency in the fall of 1898, the currency appreciated sharply and the spread over British borrowing costs fell, eventually dropping further as the restored gold standard endured. Roca announced the return to gold before congress on May 25, 1899 and resumption occurred six months later. By the end of 1902 Argentina's external borrowing spread was nearly 200 basis points lower than when Roca came to power.

Argentina's brief return to gold at the prewar parity, lasting from August 1927 and December 1929, had no such dramatic effect on its foreign borrowing costs.

\footnotetext{
${ }^{5}$ For discussions of the period, see Mitchell (1908) and Barrett (1931). Smith and Smith (1997) formally analyse exchange-rate dynamics prior to resumption.
} 
Figure 2: United States Resumption in the 1870 s

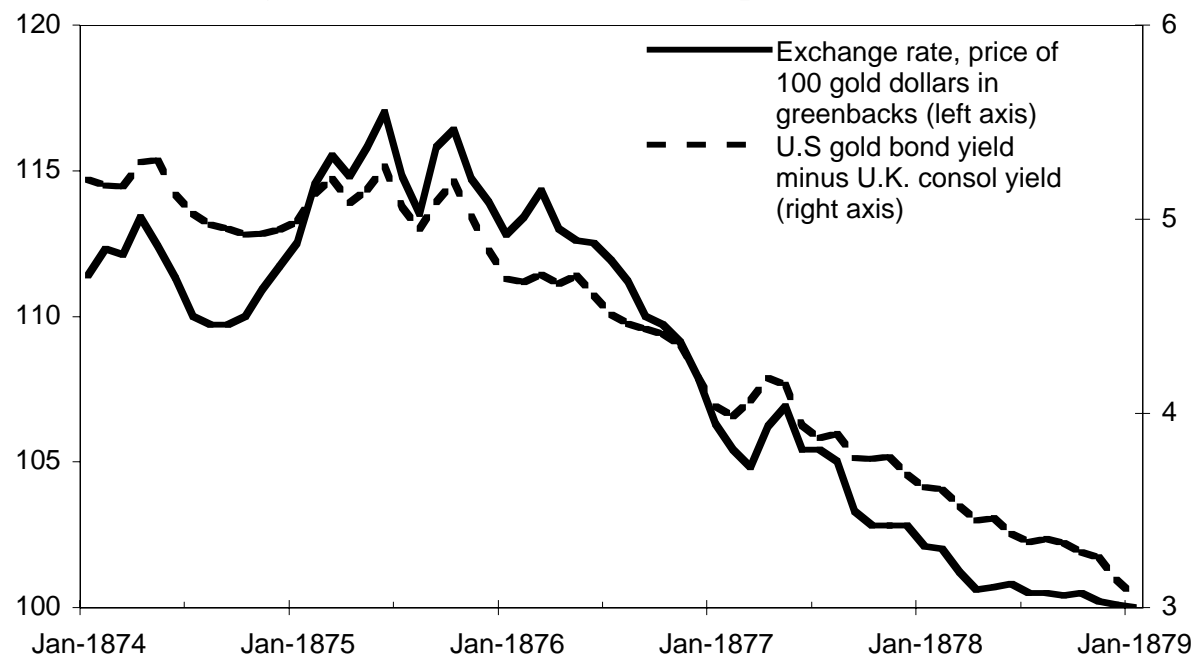

Notes: See text and appendix. Source: Global Financial Data and other sources.

Figure 3: Argentine Resumption in the 1890s

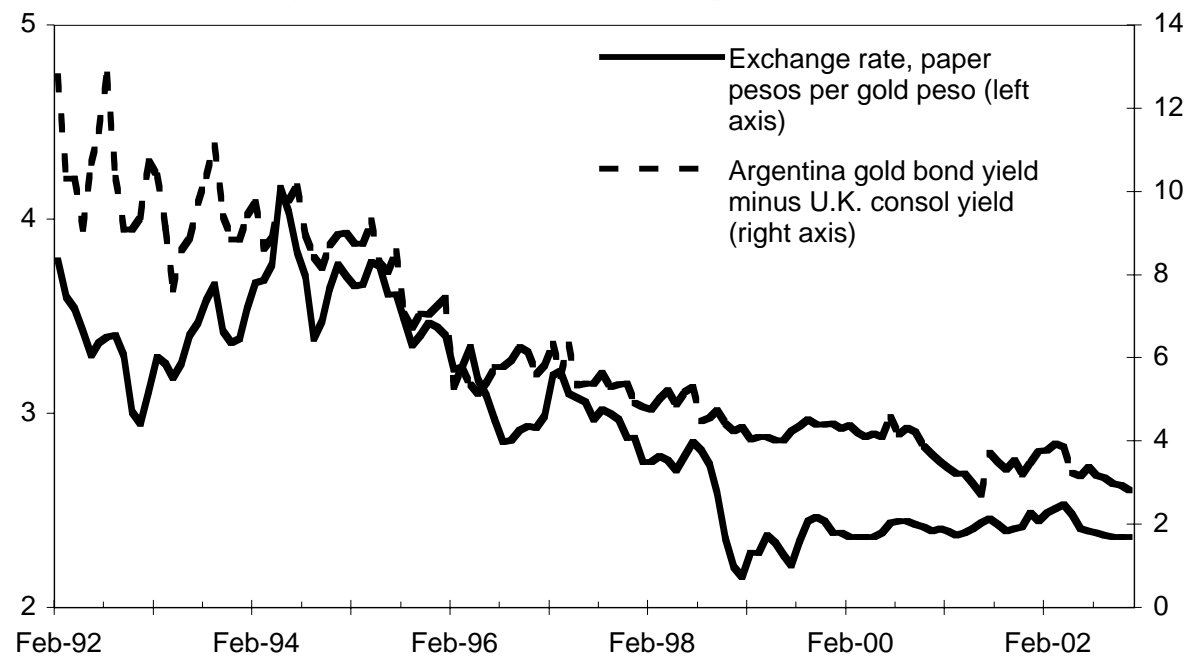

Notes: See text and appendix. Source: Global Financial Data and other sources. 
Figure 4: Australian Resumption in the 1920s

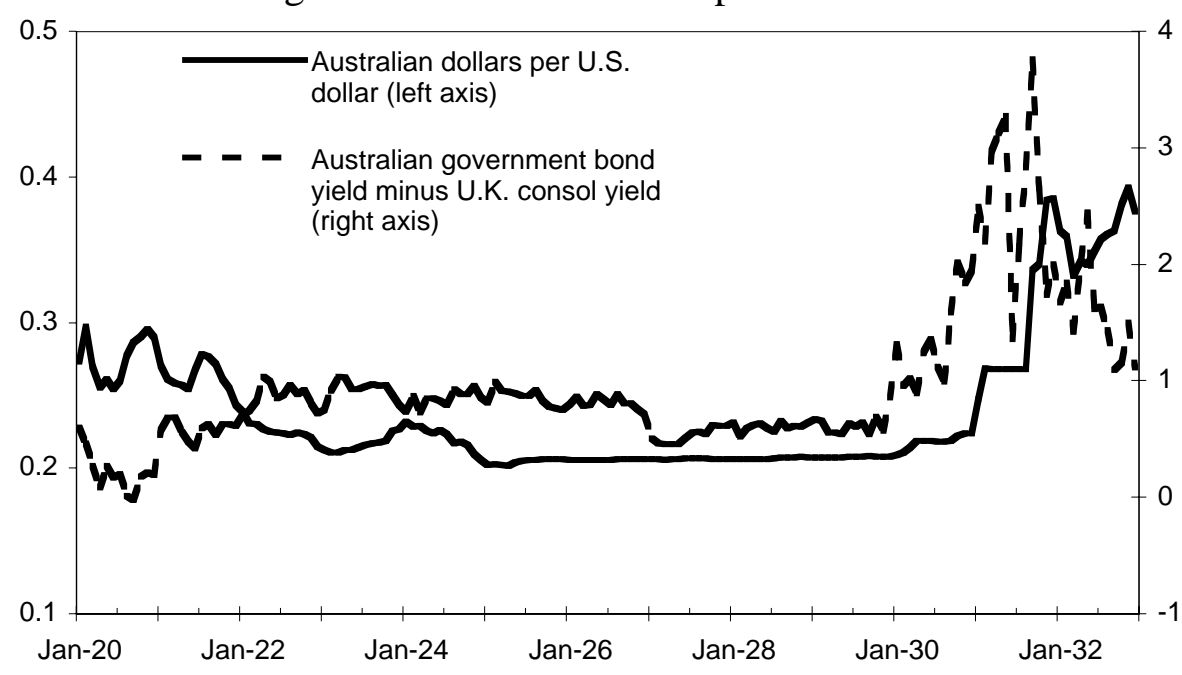

Notes: See text and appendix. Source: Global Financial Data and other sources.

The spread over U.K consols changed hardly at all over the period 1926-28. The striking contrast with the previous resumption epsiode is consistent with the view that Argentina's brief interwar gold standard had a much smaller beneficial effect on the public finances than its prewar counterpart.

Australia's experience in the 1920s resembles that of Argentina, as shown in Figure 4. Australia returned to gold at the same time as Britain (April 1925); like Britain, it returned at the prewar parity. The decline in the government's borrowing cost (relative to London), however, was delayed and rather small. Australia effectively left gold at the start of 1930, well before Britain's departure on September 19, 1931 ended the interwar gold standard. Australia's abandonment of gold was forced by severe economic problems originating in sharp falls in the prices of its commodity exports (Eichengreen, 1992, pp. 232-36). The borrowing spread over London rose sharply after Australia went off gold, but it had already begun to rise in December 1929, the month before the country effectively left the gold standard. The spread increase clearly was driven by fears of default that quickly forced the country to curtail gold convertibility, not by a progressive abandonment of gold per se. Thus, for Australia also, the interwar gold standard was less successful than its prewar predecessor in instilling confidence in foreign investors.

France's interwar return to gold offers a contrast to the two preceding cases; however, France returned to gold at a sharply devalued parity. The return occurred 
Figure 5: French Resumption in the 1920s

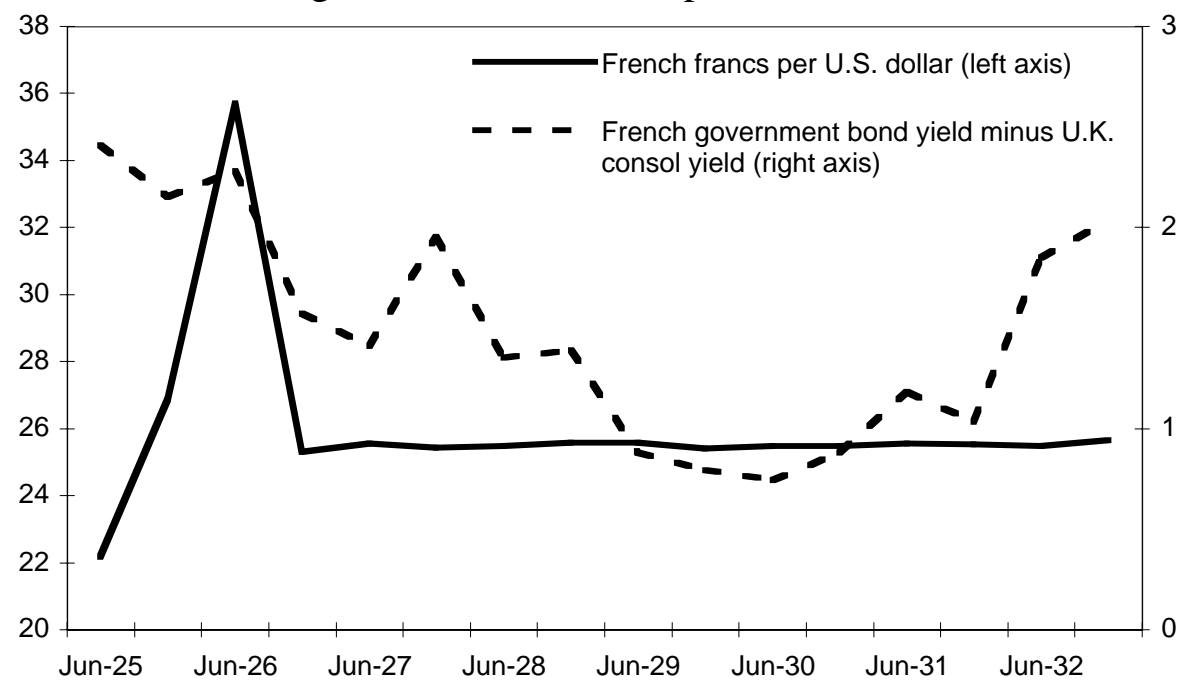

Notes: See text and appendix. Source: Global Financial Data and other sources.

in stages, and Figure 5 shows how the exchange rate (franc price of dollars) and the external borrowing spread over London covaried. Raymond Poincaré formed a government in July 1926 as the franc reached a low point, driven by a crisis of public deficits and inflation. As a result of the fiscal consolidation measures that the Poincare government immediately introduced, the franc appreciated sharply and finally was pegged in December 1926. In the period leading to this de facto embrace of gold - by then, sterling along with the dollar was linked to the metalthe external borrowing spread over London dropped sharply. This response lends support to Sargent's (1993) thesis that Poincaré's consistent fiscal and monetary reform package enjoyed great credibility in the eyes of the financial markets. That is not the end of the story, though. As Figure 5 shows, France's de jure adoption of the gold standard on June 25, 1928 was followed by a further large decline in the borrowing spread. France remained on gold long after Britain departured, and one sees that in 1932 its borrowing spread over London paper rocketed upward as the worldwide depression progressed. But for this important case of a country returning to gold at a devalued parity, adherence coincided with a large decline in the cost of foreign borrowing through September 1931.

Obviously such evidence can be suggestive only, as it fails to control for several potential determinants of spreads, so we now turn to a more formal statistical analysis of a broader sample of countries. 


\section{Econometric analysis}

We now proceed with a formal comparative analysis of sovereign borrowing risk in the prewar and interwar periods. Following Bordo and Rockoff (1996), we investigate the relationship between the dependent variable country risk, measured by the bond spread over London (measured in percentage points per annum), $\mathrm{SPREAD}_{i t}=\mathrm{YIELD}_{i t}-\mathrm{YIELD}_{U K, t}$, and selected macroeconomic policy variables that could play a role for country $i$ and time $t$. One such variable is gold standard adherence, measured by dummy variables: $\mathrm{GS}_{i t}$, which takes the value 1 if on date $t$ country $i$ is on gold at any parity, GSPAR $i t$, which takes the value 1 if on date $t$ country $i$ is on gold after 1914 at its prewar parity, and GSDEV $i t$, which takes the value 1 if the country is on gold at a devalued parity after 1914. In our interwar analysis we also introduce a heretofore unexamined dummy variable, $\mathrm{GSOFF}_{i t}$, which takes a value of 1 for countries that had adopted gold at some point but departed prior to Britain's September 1931 departure. Absent this dummy, the cost associated with leaving gold in crisis conditions would inflate our estimate of the benefit of adopting gold. But as in the Australian case discussed above, the rises in spreads that accompanied exchange rate collapses starting in 1929 were the result of global forces such as declining commodity prices and reduced capital flows, and thus were much more than a penalty for gold abandonment per se.

We also include the lagged inflation rate, $\mathrm{INFL}_{i, t-1}$. As a final macro explanatory variable, we examine the effects of lagged public debt levels, measured by the ratio of nominal debt to nominal output, DEBT $_{i, t-1}$. Country fixed effects are used to capture constant but unmeasured political, economic, institutional, or geographic features of individual countries (for example, location on the "periphery").

Like Bordo and Rockoff, we also find it necessary to account for global interest rate shocks that affect spreads in all markets in a given year. To do this, following the logic of the "international CAPM" model, we include (with a country specific slope, or " $\beta$ ") a measure of "market risk" in the form $\operatorname{SPREAD}_{W, t}=$ YIELD $_{W O R L D, t}-$ YIELD $_{U K, t}$, where this term is the GDP-weighted average world spread over the "safe rate" (London) for the countries in the sample at time $t .6$

Using pooled annual data for a large sample of countries, the basic fixed-effects regression equation is then of the form

$$
\operatorname{SPREAD}_{i t}=\alpha_{i}+\beta_{i} \operatorname{SPREAD}_{W, t}+\gamma X_{i t}+u_{i t},
$$

\footnotetext{
${ }^{6} \mathrm{We}$ experimented with other ways to control for time specific asset market shifts, such as simple time dummies, but the results appear robust.
} 
where typically the vector $X$ includes gold standard adherence, the lagged debt ratio, lagged inflation, and possibly other control variables.

Such a specification can be rationalised in a model where the government's bond rate reflects the central rate plus a default premium, and in which new government borrowing depends on the current interest rate. In that case, the regression coefficients are reduced-form coefficients incorporating the government's incentive to borrow less when the rate charged is high, but they nonethless indicate whether the gold standard and macro fundamentals affected perceived risk. When we discuss "effects" of explanatory variables on the spread below, we refer to the reduced-form regression coefficients. ${ }^{7}$

For the dependent variable SPREAD, due care must be taken in constructing measures of country risk to ensure that the bonds in every case are properly comparable across countries. We want SPREAD to capture the effects of default risk only, and not the effects of the potential exchange rate changes that are inherent in bonds' differing currency denominations. In this case, since we are using Britain as the base country, we elect to focus only on government bonds of long maturity (greater than five years, and usually at least ten) and payable in gold or sterling. It is therefore necessary to eliminate the polluting effects of Britain's departures from the gold standard-from August 1914 to April 1925 and from September 1931. Hence, we focus on only two periods: a prewar period based on annual December yields from 1870 to 1913, and an interwar period based on June yields from 1925 to 1931 . This affords us up to 44 observations in the time dimension for the prewar sample, and up to seven for the interwar sample.

To construct SPREAD we then need bond yields for each country, also payable in gold or sterling, from which we can subtract the consol yield. Finding them is not always an easy task. Because, ideally, our test requires a gold or sterling bond as quoted in London, data construction requires considerable caution. It is a well-

\footnotetext{
${ }^{7}$ Suppose that
}

$$
\operatorname{SPREAD}_{t}=a+b \mathrm{DEBT}_{t}+c Z_{t}+v_{t},
$$

where the variables $Z_{t}$ are various solvency indicators. Furthermore, suppose that new government borrowing depends negatively on the spread,

$$
\Delta \operatorname{DEBT}_{t}=-d \operatorname{SPREAD}_{t}+w_{t} .
$$

Then the reduced-form equation for the spread is

$$
\operatorname{SPREAD}_{t}=\frac{a}{1+b d}+\frac{b}{1+b d} \operatorname{DEBT}_{t-1}+\frac{c}{1+b d} Z_{t}+\frac{b w_{t}+v_{t}}{1+b d}
$$


known problem that in standard secondary sources, the attributes of a particular bond issue are not always readily apparent.

Bordo and Rockoff (1996) split their samples into gold bonds and paper bonds, finding little effect of gold standard adherence on the yields of bonds payable in domestic paper. Care is needed because many paper bonds in fact contained gold clauses or exchange clauses, which (if enforceable) would have allowed creditors to extract payment in specie or hard currency if the debtor devalued. This condition was frequently stipulated for borrowers with poor reputations for fiscal and monetary stability. Then as now, such borrowers suffered from "original sin"- that is, an inability to issue debt denominated in one's own currency. Only a handful of countries have been capable of own-currency borrowing in the last two centuries (Rousseau and Sylla, 2003). The history of nineteenth and early twentieth century bond issuance is only now being fully explored to give us some insight into the constraints that faced borrowers with respect to details of contracts, including denominations of debt issue (Bordo, Meissner, and Redish, 2002; Flandreau and Sussman, 2002). ${ }^{8}$

A great many data on bond yields are contained in the reference Global Financial Data (GFD), of which we make extensive use. For our purposes, however, we sometimes found it necessary to corroborate the type of bond quoted in GFD using bond manuals such as Kimber's Record and other sources. In many cases, the bond yields quoted in GFD failed to satisfy our requirements, being only domestic rather than London quotations, or possibly yields denominated in domestic currency, and this eliminated several countries from our database (such as Denmark in the prewar years and Spain in the interwar years). We treated the United States during the 1870s just as Bordo and Rockoff (1996) did, using Charles Calomiris's series on gold equivalent yields, for a period in which the terms of payment were in doubt (Bordo, Meissner, and Redish, 2002). Countries like Belgium, France and

\footnotetext{
${ }^{8}$ If a government's gold standard commitment had been permanent, noncontingent, and completely credible, then its paper bonds would have been "as good as gold" and any fall in external borrowing costs would have been inherited by the paper bonds. It therefore may seem puzzling that Bordo and Rockoff could not detect gold standard effects on paper yields. If countries' exchange rate commitments lacked credibility, why not their commitments to repay gold-denominated debt at par? Prewar gold standard conventions, however, allowed for suspension in the event of certain contingencies (notably, wars) provided resumption took place at the previous gold parity (Bordo and Kydland, 1995). Thus, paper bonds might entail some shorter-term exchange risk even for countries following conventional gold standard rules, whereas gold- or sterling-denominated bonds were supposedly payable in the currency of denomination regardless of the issuing government's circumstances. The different behavior of indexed and paper yields certainly warrants further investigation. Cook (2002) discusses the case of Russian bonds.
} 
Germany — which issued debt in domestic currency — had to be omitted in the prewar sample, but we were able to find interwar data on appropriately denominated Belgian and French bonds traded in New York and on the German Dawes Loan as quoted in London. Missing data were often a problem too. Some of the gaps in GFD, especially in the interwar years, could be filled by consulting newspapers such as the Investor's Monthly Manual (for a London quote) or, as a last resort, the Wall Street Journal (for New York quotes on gold-linked bonds). Full details of the construction of the yield data are in the appendix.

Other complications affect our use of historical bond yield data. The compiler of the GFD source, Bryan Taylor, warns in the documentation (September 2000) that: "For riskier issues, such as Latin American countries, not only was there a risk that coupons could be eliminated, but that the entire issue could go in default. At that point, the implied yield becomes meaningless, and any yield over $10 \%$ before World War Two should be treated as implying that the issue was in default on either coupon, on principal, or on both." Because our model is intended to capture country risk under conditions with a positive probability of full repayment, once an issue actually is in default we might expect its yield to be volatile indeed, and perhaps far removed from any simple linear prediction given by a model of the form (1). Such defaults were not uncommon in our data, and in some cases spreads grew to 20, 30 or even 60 percentage points on some issues, implying prices of less than $10 \%$ of par value.

Although such steep discounts on bonds affect only a small part of our sample, we discuss below the steps we can take to ensure that these types of observation do not bias the regression estimates. As might be expected, many of these observations correspond to periods of severe political unrest or uncertainty associated with revolutions (e.g., Mexico in the 1920s), civil wars and their aftermath (e.g., Uruguay in the 1870s), or similar disturbances. This is not to deny that military strife is often a key determinant of bond yields (Ferguson, 2001), but we are not so naive as to claim that a model like (1) might function well with merely the addition of dummies or qualitative variables for "War," "Assassinations," and the like. Instead, we concentrate on a narrower and cleaner specification where a positive probability of full repayment also presupposes sufficient political stability to make linear approximations meaningful. ${ }^{9}$

\footnotetext{
${ }^{9}$ Still, it is certainly a worthy topic for future research to expand this kind of model to include measures of conflict, whether internal or external, political or military. To quantify the nature of any given war would appear intractable, however. A more profitable direction might be to experiment with other determinants of country risk including now-standard "institutional" measures such as democracy, rule of law, property rights, and so on.
} 
For independent variables we centre our analysis on the key policy regime variable that was, during this era, at the heart of monetary policy: the adoption or suspension of the gold standard. We construct a dummy variable GS that reflects each country's position in a given year on this policy dimension (on gold equals one, and off equals zero). The appendix gives details of our coding procedure, which of necessity involves somewhat subjective judgements even for such an apparently clear-cut variable as gold-standard adherence. Several countries (notably Spain and Italy before 1914) spent many years posturing as "shadow" members of the gold standard-fixing and defending their exchange rate, yet not fully embracing gold convertibility or other "rules of the game." In the classifications of many scholars this leads to a delicate decision as to whether such cases should be treated as on or off gold (see, e.g., Martín Aceña, 2000; Fratianni and Spinelli, 1984).

The situation during the interwar period is murkier still. After World War One, many countries first stabilised their currencies de facto with respect to gold, moving only gradually toward the de jure embrace of gold standard rules. Similarly, exits from the gold standard starting in 1929 sometimes were accomplished in piecemeal fashion, a first step often being some sort of formal or informal government control over gold outflows. Indeed, the tendency of governments to tinker with the interwar gold standard is a key reason scholars have viewed it as imperfectly credible. Our classification corresponds largely to de jure gold standard adherence, as we describe in the appendix. ${ }^{10}$

The other economic control variables in our model allow fiscal, monetary, and macroeconomic conditions to affect country risk. DEBT is a measure of the public debt to GDP ratio of the country (lagged one year), typically based on central government debt. This variable is included to allow for the possibility that markets might impose more severe credit conditions on highly indebted governments, where, ceteris paribus, default risk is higher. INFL is a measure of the rate of price inflation (lagged one year). Because many countries operated on fractional gold

\footnotetext{
${ }^{10}$ Our interwar dates, although generally in agreeement with those of Officer (2001), contradict in a number of cases the annual codings reproduced in Eichengreen (1992, pp. 188-90).

A general problem with the type of coding we use is that reinstatement of gold was in some cases anticipated (recall Section 2), with some fraction of the beneficial spread effects possibly front-loaded. In that case our estimates of the benefit of gold adherence could be biased downward. One way to deal with the problem within this paper's framework might be through anticipatory dummies. In our view, however, the diverse circumstances of countries' paths back to gold warrant a case-by-case analysis with more detailed macroeconomic and political control variables than are available for broad cross-sectional work. This we leave for future research. In cases such as that of interwar France (Section 2), for example, one would ideally disentangle the benefits of gold from those of the Poincaré stabilisation measures that made de jure resumption possible two years later.
} 
backing, this variable could be important as a way for markets to detect slippage in gold standard commitments by governments, for example, at the start of episodes of overvaluation that might lead to reserve loss followed by eventual suspension and debt crisis. ${ }^{11}$ These two variables have straightforward interpretations as policy descriptors.

We also add two more economic variables often seen in country risk studies. The first is EXPORTS, a measure of the export to GDP ratio, which reveals the capacity of the country to earn the foreign exchange needed to service externallyheld debt. This indicator is commonly used as a risk measure today by emerging market credit analysts. A final variable, LOGY, a measure of real income per capita (relative to the sample mean), serves as a catch-all variable that proxies for all manner of social, political, institutional and financial developments along the road to modernisation that might make a country a better credit risk. ${ }^{12}$

The gradual convergence of bond spreads evident in Figure 1 warns us that the dynamics of evolving country risk might not be simple. In particular, the figure suggests high levels of persistence or serial correlation in bond spreads, and it is easy to imagine why. Bond spreads are a function of reputation, which in capital markets, as in any other repeated game, cannot be built overnight. Instead, one's reputation in the previous period is likely to have a substantial influence on one's reputation today. In our empirical results we present two alternative estimates based on different approaches to modelling of the persistence in spreads. One way is to impound all of the persistence in the error term, using an AR1 model. Another way is to use a lagged dependent variable model, so that spreads themselves follow a partial adjustment process towards long-run equilibrium.

\subsection{Prewar findings, 1870-1913}

As a cross check we begin our analysis with a simple attempt to replicate the findings of Bordo and Rockoff (1996), who used a sample of just seven countries in the prewar era, Argentina, Australia, Brazil, Canada, Chile, Italy and the United States. Based on pooled data for gold bonds (267 observations), their headline number for the impact of the gold standard on country risk was presented as follows:

\footnotetext{
${ }^{11}$ Bordo and Rockoff (1996) use the gap between money growth and real output as their measure of monetary laxity, but, even if we do not assume a stable velocity, the outcome variable INFL can serve as an adequate measure of excess money supply growth.

${ }^{12}$ Real income per capita (at PPP prices) and the export ratio were included in the pre-1914 country risk analysis of Flandreau et al. (1998).
} 
Indeed, if we were to single out one number to represent our findings with respect to the significance of the gold-adherence dummy it would be 40 basis points.... In other words, all other things equal, the rate on a gold bond would be 40 basis points lower if the country were on the gold standard. Other factors, perhaps related to regional preferences, undoubtedly also played a role in determining country-risk premia. But our analysis suggests a willingness to commit to the gold standard was an important determinant of risk premia established in the London capital market. (Bordo and Rockoff, 1996, p. 413.)

We are in broad agreement with this conclusion. Regression 1 of Table 1 shows that our data, some of it from different sources, enables us to duplicate the Bordo-Rockoff finding on their country sample. We have slightly longer time series that yield 301 observations for the Bordo-Rockoff countries, but we find, as they did, that adopting the gold standard was worth a reduction in spread of about 40 basis points. The effect is highly statistically significant. As Bordo and Rockoff noted, strong serial correlation in this context renders ordinary least squares (OLS) invalid, so like them we employ an AR1 specification, allowing for possibly different autoregressive parameters in each member of the panel. ${ }^{13}$ That is we estimate an equation of the form (1) under the assumption that $u_{i t}=\rho_{i} u_{i, t-1}+\epsilon_{i t}$ and $\epsilon_{i t}$ are white noise disturbances.

Here, and throughout this section, the $\beta_{i}$ coefficients are not shown to conserve space but they also accord with expectations and past results, being higher in "riskier" peripheral countries. Country fixed effects, which are reported, are high for peripheral countries such as Brazil (237 basis points), Italy (172), Argentina (180), and Chile (160), but lower for the core western offshoots, Australia, Canada, and the United States (101, 41, and 34 basis points, respectively).

Regression 2 now expands this analysis substantially by using our augmented data set covering more than 20 countries from 1870 to 1913 . The sample size here increases by a factor of nearly three, to 871 observations. The model performs poorly in that the estimated effect of the gold standard (again roughly 40 basis points) is not statistically significant at conventional levels. Still, we find that this result is an artefact of a few badly-behaved outliers in the data. Specifically,

\footnotetext{
${ }^{13}$ Unlike Bordo and Rockoff (1996), we do not employ SUR models, but we have explored SUR results for limited samples and find the results broadly similar. However, the larger cross-section size in our later regressions calls for a large parameter set in the unrestricted error covariance matrix under SUR, sometimes too large a set for the available degrees of freedom. In all of our tables, the country coefficients identified vertically along the left are the country-specific intercepts.
} 
Table 1: Country Risk and the Gold Standard, 1870-1913

\begin{tabular}{|c|c|c|c|c|c|}
\hline \multirow{3}{*}{ Sample } & $(1)$ & (2) & (3) & (4) & $(5)$ \\
\hline & Bordo & All & SPREAD & SPREAD & SPREAD \\
\hline & Rockoff & & $<20$ & $<15$ & $<10$ \\
\hline Observations & 301 & 871 & 856 & 848 & 831 \\
\hline$R^{2}$ & 0.92 & 0.94 & 0.89 & 0.88 & 0.87 \\
\hline$\overline{G S}$ & $-0.43(3.38)$ & $-0.44(1.60)$ & $-0.61(2.99)$ & $-0.54(2.97)$ & $-0.35(2.61)$ \\
\hline $\mathrm{ARG}$ & $1.80(5.57)$ & $1.78(1.79)$ & $1.93(2.85)$ & $1.89(3.10)$ & $1.72(3.38)$ \\
\hline AUS & $1.01(4.79)$ & $1.02(1.79)$ & $1.18(2.83)$ & $1.12(2.98)$ & $0.93(3.18)$ \\
\hline AUT & - & $-0.14(0.11)$ & $-0.14(0.15)$ & $-0.14(0.17)$ & $-0.14(0.21)$ \\
\hline BRZ & $2.37(6.38)$ & $2.33(2.03)$ & $2.46(3.09)$ & $2.43(3.40)$ & $2.30(3.91)$ \\
\hline CAN & $0.41(1.04)$ & $0.42(0.37)$ & $0.59(0.70)$ & $0.52(0.69)$ & $0.33(0.56)$ \\
\hline $\mathrm{CHL}$ & $1.60(4.92)$ & $1.61(1.68)$ & $1.61(2.24)$ & $1.61(2.49)$ & $1.60(3.22)$ \\
\hline EGY & - & $-0.94(0.97)$ & $-0.78(1.09)$ & $-0.84(1.31)$ & $0.10(0.18)$ \\
\hline GRC & - & $-3.70(4.55)$ & $3.09(3.53)$ & $2.05(1.44)$ & $2.21(1.97)$ \\
\hline IND & - & $0.44(0.28)$ & $0.52(0.40)$ & $0.48(0.41)$ & $0.38(0.46)$ \\
\hline ITA & $1.72(6.31)$ & $1.75(2.44)$ & $1.77(2.81)$ & $1.75(3.11)$ & $1.71(4.50)$ \\
\hline JPN & - & $2.48(2.30)$ & $2.57(3.95)$ & $2.51(4.28)$ & $2.39(4.42)$ \\
\hline MEX & - & $-4.93(4.62)$ & $-0.40(0.45)$ & $-0.79(0.72)$ & $-0.62(0.67)$ \\
\hline NOR & - & $0.58(0.48)$ & $0.74(0.84)$ & $0.68(0.86)$ & $0.49(0.78)$ \\
\hline NZL & - & $0.80(0.61)$ & $0.96(1.00)$ & $0.90(1.05)$ & $0.71(1.04)$ \\
\hline PRT & - & $1.74(1.54)$ & $1.76(2.11)$ & $1.75(2.34)$ & $1.73(7.58)$ \\
\hline RSA & - & $1.28(0.74)$ & $1.44(1.14)$ & $1.38(1.22)$ & $1.19(1.33)$ \\
\hline SPA & - & $-4.51(4.69)$ & $-3.66(6.21)$ & $-1.51(4.36)$ & $-0.32(0.67)$ \\
\hline SWE & - & $0.76(0.82)$ & $0.92(1.42)$ & $0.86(1.48)$ & $0.68(1.43)$ \\
\hline TUR & - & $0.10(0.11)$ & $0.26(0.38)$ & $0.20(0.33)$ & $0.01(0.01)$ \\
\hline USA & $0.34(0.88)$ & $0.37(0.33)$ & $0.56(0.72)$ & $0.48(0.68)$ & $0.24(0.42)$ \\
\hline URU & - & $-0.69(0.39)$ & $-0.53(0.41)$ & $-0.59(0.51)$ & $-0.30(0.33)$ \\
\hline $\min \left(\rho_{i}\right)$ & 0.33 & 0.33 & 0.33 & 0.33 & 0.23 \\
\hline $\max \left(\rho_{i}\right)$ & 0.75 & 0.88 & 0.89 & 0.88 & 0.88 \\
\hline Mean empire & - & $0.50(0.88)$ & $0.65(1.52)$ & $0.60(1.54)$ & $0.61(2.03)$ \\
\hline Mean nonempire & - & $-0.03(0.10)$ & $0.86(3.63)$ & $0.88(3.82)$ & $0.91(5.05)$ \\
\hline Difference (Empire effect) & - & $0.53(0.91)$ & $-0.21(0.48)$ & $-0.28(0.69)$ & $-0.31(0.97)$ \\
\hline
\end{tabular}

Notes: Dependent variable is SPREAD. Country-specific $\beta_{i}$ and $\rho_{i}$ are not reported; $t$-statistics are shown in parentheses. Mean empire and mean nonempire show average fixed effect for the group. Sources: See text and appendix. 
when we exclude observations with very high spreads (over 2,000 or 1,500 or 1,000 basis points) as in Regressions 3, 4 and 5, we find that the effect of the gold standard is strong and statistically significant, though the effect is a little smaller in Regression 5, where truncation is more severe, and bigger in the other regressions. These findings requires the exclusion of very few data points, since even Regression 5, the most restrictive, still has 831 observations, a loss of less than $5 \%$ of the sample. Of course, these are the data points that correspond to issues in default trouble, often the result of military or political crises, as noted above. Accordingly, we proceed on the assumption that our country risk model is adequate for less dire circumstances. ${ }^{14}$

Our broader aim is to consider the role of additional country characteristics in determining country risk. Since certain geopolitical features of countries remained fairly constant in this period, a natural place to start is by examining the country fixed effects for clues. And since Britain is being used as the reference country in the analysis, an important feature to examine would be any special country-specific links to Britain. An obvious criterion is membership in the British Empire.

Ever since Marx and Hobson, students who view history through the lens of political economy - whether from left, right or centre - have regarded imperialism as a leading vehicle on the road to economic globalisation. Its epitome, the British Empire, is seen as, amongst other things, a privileged economic zone in both trade and capital markets. Empire connections among countries are believed to have conveyed some distinct advantages to would-be borrowers in London. Davis and Huttenback (1986) and Edelstein (1981) have suggested that Empire membership meant a lower cost of capital to both public and private sectors in this era.

Taking the argument further, Ferguson (2002) places these ideas in the context of a broader political and financial history and claims support, on economic if not on other grounds, for his case that the British Empire was a global public good:

My hypothesis is that empire - and particularly the British Empireencouraged investors to put their money in developing economies. The reasoning is straightforward. Investing in such economies is risky. They tend to be far away and more prone to economic, social and political crises. But the extension of empire into the less developed

\footnotetext{
${ }^{14}$ Due to the more restricted samples for which data on the additional control variables are available, we virtually never again encounter observations with spreads larger than 1,000 basis points. The only exceptional case is that of interwar Mexico, which, being still in the throes of post-revolutionary instability, exhibited high and volatile spreads and therefore is excluded from our analysis.
} 
world had the effect of reducing such risks by imposing, directly or indirectly, some form of European rule. In practice, money invested in a de iure British colony such as India (or a colony in all but name like Egypt) was a great deal more secure than money invested in a de facto "colony" such as Argentina.

This effect should be-and is-quantifiable. There are two ways of posing the crucial question. First, did the existence of the British Empire make investors more willing to put their money into poorer countries than they would otherwise have been? More precisely, did being a British colony reduce the cost of borrowing for a country? The hypothesis here is that it did, because being a colony implied a no-default guarantee. This was arguably a better "seal of good housekeeping" even than membership of the gold standard, though most British colonies had both. (Ferguson, 2002, p. 12.)

Here, one contrast to the Bordo and Rockoff (1996) claim is quite explicit. Empire, not the gold standard, was what really counted for attracting capital in large quantities at low cost, though the two forces need not have been mutually exclusive and, indeed, were positively correlated. To settle the debate econometrically, however, requires careful controls for these and other risk determinants.

It is imperative, then, that we consider the "Empire effect" in our analysis. The question is whether countries within the Empire enjoyed preferential access to the market, and we interpret that to imply that, all else equal, Empire countries should exhibit a smaller fixed effect than others. This can be studied by looking at each individual intercept in the regression. Or, for a summary comparison of the two groups, we can ask whether the mean fixed effect in the empire group was less than the mean in the nonempire group. The mean fixed effect for each group is shown in the bottom panel of Table 1, together with the $t$-statistic for the estimated mean (where the null is a zero mean).

Our results are not too favorable to the idea of an "Empire effect" during the so-called Age of High Imperialism. In Regression 2 even the sign is wrong. In the possibly more robust regressions ( 3,4 , and 5$)$ the sign is correct, and Empire membership seems to be worth about 20 to 30 basis points as a point estimate; but this was no more valuable than going on gold—and, unlike the effect of gold, this impact is not statistically significant. ${ }^{15}$

\footnotetext{
${ }^{15} \mathrm{~A}$ "strong" test of the Empire hypothesis would be to also require the $\beta$ coefficients to be zero for Empire members. That would imply that their returns did not co-vary with changes in the
} 
A detailed look at some of the fixed effects reveals some of the problem cases. Consider Regression 5. In the nonempire group only some countries (once we include the effect of being on gold) paid a large risk penalty, namely Argentina (about 137 basis points), Brazil (195), Chile (125), Greece (186), Italy (136), Japan (204), and Portugal (138). Others appear to have paid no premium at all. Yet even the richest country in the world (by some measures) and Empire member Australia had to pay a statistically significant risk premium of about 58 basis points, though no other Empire countries were so burdened. ${ }^{16}$

The reasons for Australia's plight are easy to guess, given the severe and enduring consequences of the widespread defaults associated with the $1890 \mathrm{crash}$ and subsequent depression, which crippled Australia's banks and dented the country's reputation in the London market (see Davis and Gallman, 2001). The Australian results show that, even if empire borrowers were proof against outright sovereign default, they were not proof against a severe economic crisis. Some narrative evidence seems to back this up, as British and empire issues were not always viewed as pure substitutes by outside observers with a keen eye on the determinants of risk premia. ${ }^{17}$

Conversely, even some peripheral nonempire countries such as Uruguay (which was well within "contagion range" of Argentina and Brazil) seemed not to have been penalised in capital markets despite being outside the formal empire. Empire status was neither necessary nor sufficient for preferential access to the London market. Much seemed to depend on other aspects of the behavior of the borrowerfor our purposes, an unobservable.

In Table 2 we use the full data set to check the robustness of the preceding results to additional controls for debt ratios, inflation, and relative income per capita. Regression 1 in Table 2 adds DEBT and INFL to the spread equation. As we noted in the introduction, the omission of DEBT in particular could very plausibly lead to biases. ${ }^{18}$ We are now restricted to a much smaller sample than in

global spread-in other words, that they were "safe" assets like the British consol itself, up to a white noise error. But this hypothesis is very decisively rejected. Although the $\beta$ coefficients are not reported in the tables to conserve space, these results are available from the authors on request.

${ }^{16}$ These estimates are 35 basis points less than the reported intercepts because we also include the effect of going on gold.

${ }^{17}$ For example, during the Japanese government's internal debate over investing foreign reserves during the mid-1890s, the finance minister asked "Are the public bonds of the Indian Government as safe and reliable as those of England itself?" (Matsukata, 1899, p. 221).

${ }^{18}$ Flandreau et al. (1998) argue that a major factor driving the evident convergence of bond spreads after the early 1890s and through 1914 is worldwide inflation resulting from gold discoveries, a factor that caused both an unexpected reduction in countries' ratios of public debt to nominal 
Table 2: Country Risk and the Gold Standard, 1870-1913: Additional Controls

\begin{tabular}{lcccc}
\hline \hline & $(1)$ & $(2)$ & $(3)$ & $(4)$ \\
\hline Observations & 546 & 546 & 546 & 546 \\
$R^{2}$ & 0.85 & 0.85 & 0.85 & 0.85 \\
\hline GS & $-0.50(2.57)$ & $-0.50(2.58)$ & $-0.50(2.58)$ & $-0.49(2.58)$ \\
DEBT & $0.12(0.58)$ & $-0.44(0.86)$ & $-0.06(0.16)$ & $-0.01(0.05)$ \\
INFL & $0.21(0.68)$ & $0.90(0.63)$ & $0.41(0.57)$ & $0.13(0.44)$ \\
DEBT $\times$ periphery & - & $0.63(1.13)$ & - & - \\
INFL $\times$ periphery & - & $-0.71(0.48)$ & - & - \\
DEBT $\times$ nonempire & - & - & $0.25(0.56)$ & - \\
INFL $\times$ nonempire & - & - & $-0.22(0.28)$ & - \\
EXPORTS & - & - & - & $0.71(0.64)$ \\
LOGY & - & - & - & $-0.88(2.50)$ \\
ARG & $0.60(0.60)$ & $0.56(0.57)$ & $0.57(0.57)$ & $7.79(2.53)$ \\
AUS & $0.96(2.50)$ & $1.54(2.50)$ & $1.14(2.29)$ & $8.35(2.75)$ \\
AUT & $0.00(0.00)$ & $-0.08(0.09)$ & $-0.07(0.08)$ & $6.77(2.27)$ \\
BRZ & $1.04(0.95)$ & $0.93(0.84)$ & $0.95(0.86)$ & $6.97(2.66)$ \\
CAN & $0.18(0.25)$ & $0.17(0.25)$ & $0.21(0.29)$ & $7.52(2.49)$ \\
CHL & $1.46(3.04)$ & $1.43(2.96)$ & $1.43(2.93)$ & $8.20(2.94)$ \\
EGY & $0.67(0.87)$ & $0.69(0.90)$ & $0.60(0.79)$ & $6.37(2.58)$ \\
IND & $0.67(1.27)$ & $0.65(1.22)$ & $0.73(1.37)$ & $6.26(2.68)$ \\
ITA & $1.58(1.38)$ & $1.52(1.32)$ & $1.52(1.32)$ & $8.22(2.83)$ \\
JPN & $0.46(0.53)$ & $0.41(0.47)$ & $0.41(0.47)$ & $6.70(2.50)$ \\
NOR & $0.62(0.75)$ & $0.73(0.91)$ & $0.60(0.73)$ & $7.32(2.59)$ \\
NZL & $0.25(0.25)$ & $0.80(0.77)$ & $0.43(0.41)$ & $7.65(2.35)$ \\
PRT & $1.48(2.35)$ & $1.42(2.24)$ & $1.42(2.22)$ & $7.91(2.99)$ \\
SPA & $-1.72(1.89)$ & $-1.82(1.98)$ & $-1.82(1.95)$ & $5.13(1.77)$ \\
SWE & $0.61(0.61)$ & $0.69(0.69)$ & $0.60(0.60)$ & $7.82(2.60)$ \\
USA & $0.49(0.59)$ & $0.49(0.58)$ & $0.49(0.59)$ & $7.88(2.55)$ \\
URU & $-0.78(0.82)$ & $-0.86(0.90)$ & $-0.85(0.88)$ & $6.24(2.10)$ \\
min $\left(\rho_{i}\right)$ & 0.29 & 0.12 & 0.30 & 0.21 \\
max $\left(\rho_{i}\right)$ & 0.83 & 0.84 & 0.84 & 0.82 \\
\hline Mean empire & $0.54(1.49)$ & $0.77(1.84)$ & $0.62(1.59)$ & $7.23(2.63)$ \\
Mean nonempire & $0.49(1.51)$ & $0.45(1.40)$ & $0.44(1.30)$ & $7.24(2.62)$ \\
Difference (Empire effect) & $0.06(0.15)$ & $0.32(0.69)$ & $0.18(0.40)$ & $-0.01(0.04)$ \\
\hline \hline Nores $a m s o u r c s: S e c$ & & & &
\end{tabular}

Notes and Sources: See Table 1. 
Table 1, since our new variables DEBT and INFL are not available for all countries in all years. From a maximum of 871 observations, we are now down to 546. For this pre-1914 sample, the gold standard seal of approval is still strong in all of the regressions (and estimated to be at or near 50 basis points).

Perhaps surprisingly, neither DEBT nor INFL is significant in Regression 1, although both are correctly signed. The gold standard commitment appeared strong enough that markets could rely on contained inflation and debt repayment. In an interesting twist, we also find that the Empire thesis is again rejected, but for a more powerful reason. In this smaller subsample, all countries could expect, once on gold, to converge to the British bond yield.

Regression 2 performs a different kind of robustness check. What if the markets priced risk differently among mature versus emerging debtors, or core versus periphery? To test this we partitioned the sample into core and periphery, and then interacted the macroeconomic variables DEBT and INFL with the periphery dummy (defined in the appendix). The results show that, at conventional significance levels, the hypothesis that periphery risk was priced differently can be rejected, although there is a hint that high periphery debt levels were punished rather more severely on the margin. Here once again, as in all specifications in Table 2, the "Empire effect" is found to be statistically indistinguishable from zero based on the difference between the mean fixed effects.

Regression 3 attempts to resuscitate the "Empire effect" another way. Perhaps the advantages of Empire were not a lower unconditional level of country risk, but a more tolerant view of debt and inflation variables by the markets? As in Regression 2 we test this hypothesis by interacting an Empire dummy variable with the macroeconomic variables DEBT and INFL. The hypothesis is rejected at usual significance levels. Default prospects were not priced significantly differently in Empire countries by this yardstick either, despite a faint hint of stronger debt punishment for non-empire borrowers.

GDP and a more widespread adherence to the gold standard. For the pre-1914 period, Flandreau et al. investigate borrowing spreads over London using a country sample different from that of Bordo and Rockoff (1996) and an econometric specification encompassing the public debt ratio to GDP as well as gold standard adherence. Unlike us, they find a strong positive effect of public debt on borrowing spreads even under the classical gold standard (and even in a linear model of spread determination). Unfortunately, we have not been able to obtain their complete data set, which includes some "European peripheral" countries with highly indebted governments, so we cannot say for sure whether differences in the country sample drive the discrepancy in results. The Flandreau et al. estimates of the value of gold standard adherence before 1914 are, as we noted above, similar to those that we and Bordo and Rockoff find. 
In Regression 4 we assess the impact of the two economic additional control variables EXPORTS and LOGY. Export ratios seem to have had no statistically significant impact on the risk premium, but the level of development turns out to be highly statistically significant, as might have been expected. "Less developed" countries (as measured by income per capita) faced higher country risk. As noted, the statement of this result is simpler than its interpretation. Does LOGY measure some economic attraction such as productivity? Or is it a proxy for some institutional development, whether legal, financial or political? Whatever its meaning - it is perhaps best seen as a continuous alternative to the dichotomous periphery dummy - we find strong evidence to support the inclusion of such a control variable. However, its inclusion alters none of our previous main findings. In particular, debt appears not to matter and the inflation coefficient, while of the right sign, is statistically insignificant.

For a final sensitivity check we adopted a different specification than any employed in the literature so far, and one that might be more robust since it does not depend on such strong assumptions. First, we augment the model (1) to include a lagged dependent variable, so that we estimate

$$
\operatorname{SPREAD}_{i t}=\alpha_{i}+\phi(L) \mathrm{SPREAD}_{i t}+\beta_{i} \operatorname{SPREAD}_{W, t}+\gamma X_{i t}+u_{i t},
$$

where $\phi(L)$ is a polynomial in positive powers of the lag operator $L$. We retain fixed effects and possible serial correlation. This choice of model could be justified on a number of grounds. Lagged-dependent variable models can be hard to distinguish from the previous AR1 models we have used, but they might better approximate bond market behavior if agents employ Bayesian updating of country risk. In that setting, today's predicted risk is a linear combination of lagged risk and today's new information. Thus, deviations from steady state risk may persist for a long time, whereas in the simple AR1 model the fitted value adjusts immediately and only the error term has persistence.

Naturally, such a flexible form as this calls for a different estimation strategy. Panel fixed effects with lagged dependent variables induce bias in OLS estimates, and the solution is to use the generalised method of moments (GMM). We employ the Arellano and Bond (1991) one-step dynamic panel estimator, treating the world risk and gold standard variables as exogenous, and the lagged debt and inflation terms as endogenous but predetermined. The model is estimated in differences using at least twice lagged levels of the endogenous variables as instruments. Selected results are shown in Table 3, and, despite the very different estimation 
strategy, they show a basic consistency with the message from Tables 1 and $2 .{ }^{19}$ The long-run effect of the gold standard on country risk is now about 65 basis points and generally statistically significant, suggesting that the Bordo-Rockoff methodology might have slightly understated the benefits of the gold standard. The other coefficients are statistically insignificant, although inflation has economically significant estimated effects across the four specifications. In the final column EXPORTS is statistically insignificant, and LOGY has a marginal significance level (8 perecent), leading us to select the first column as our preferred GMM prewar specification. Since the GMM model is estimated in differences, all fixed effects drop out, meaning that this framework is necessarily silent on the "Empire effect."

Like Bordo and Rockoff (1996), we conclude overall that the main significant policy determinant of country risk in the prewar period appears to have been gold standard adherence. Gold was apparently a good enough seal of approval by itself, and risk was priced without much reference to public debt levels, inflation, or whether the country was core or periphery, empire or nonempire.

\subsection{Interwar findings, 1925-31}

Most narrative accounts of the transition from the classical gold standard to the interwar period stress one key difference: the rebuilt gold standard was a pale imitation of its predecessor. It did not long endure, and seemed to lack both credibility and stability. As Temin (1989, p. 33) remarks, "The combination of changed conditions and some policy choices of the 1920 s ... created great strains in the operation of the interwar gold standard."

The key question is whether such a regime change can be detected in the data. To that end we repeat the previous country risk modelling exercise for the period 1925-31. One difficulty here is that after 1914, many countries suspended and then resumed the gold standard at new, devalued parities that partially expropriated prior bondholders. In a conventional view of reputation (Bordo and Kydland, 1995), devaluation would be viewed with suspicion by markets, and fear of such reactions prompted some governments to deflate in order to restore prewar parities-Churchill's pursuit of $\$ 4.86$ is perhaps the most famous example. To account for differential market treatment of par maintainers and par adjusters, we use the policy dummy variables GSPAR and GSDEV described at the start of this

\footnotetext{
${ }^{19}$ In these regressions, preliminary analysis indicated the need for two lags to ensure no second order residual autocorrelation.
} 
Table 3: Country Risk and the Gold Standard, 1870-1913: GMM Estimates

\begin{tabular}{|c|c|c|c|c|}
\hline & (1) & (2) & (3) & (4) \\
\hline Observations & 546 & 546 & 546 & 546 \\
\hline Sargan & $466.27[0.00]$ & $492.00[0.00]$ & $531.95[0.00]$ & $574.76[0.00]$ \\
\hline$m_{2}$ & $-0.26[0.79]$ & $-0.25[0.80]$ & $-0.34[0.73]$ & $-0.75[0.45]$ \\
\hline SPREAD(t-1) & $0.70(19.43)$ & $0.70(19.96)$ & $0.71(20.32)$ & $0.74(21.13)$ \\
\hline SPREAD(t-2) & $-0.32(10.07)$ & $-0.31(10.10)$ & $-0.31(9.96)$ & $-0.28(9.03)$ \\
\hline GS & $-0.40(2.17)$ & $-0.38(2.17)$ & $-0.39(2.31)$ & $-0.20(1.24)$ \\
\hline DEBT & $0.03(0.17)$ & $-0.27(0.55)$ & $-0.15(0.57)$ & $-0.08(0.61)$ \\
\hline INFL & $0.53(1.55)$ & $1.17(0.92)$ & $0.35(0.50)$ & $0.34(1.08)$ \\
\hline DEBT $\times$ periphery & - & $0.32(0.62)$ & - & - \\
\hline INFL $\times$ periphery & - & $-0.68(0.51)$ & - & - \\
\hline DEBT $\times$ nonempire & - & - & $0.14(0.45)$ & - \\
\hline INFL $\times$ nonempire & - & - & $0.19(0.25)$ & - \\
\hline EXPORTS & - & - & - & $0.76(0.74)$ \\
\hline LOGY & - & - & - & $-0.92(1.71)$ \\
\hline \multicolumn{5}{|l|}{ Long-run coefficients } \\
\hline GS & -0.65 & -0.63 & -0.63 & -0.33 \\
\hline DEBT & 0.04 & -0.44 & -0.25 & -0.13 \\
\hline INFL & 0.86 & 1.90 & 0.57 & 0.56 \\
\hline DEBT $\times$ periphery & - & 0.53 & - & - \\
\hline INFL $\times$ periphery & - & -1.10 & - & - \\
\hline DEBT $\times$ nonempire & - & - & 0.22 & - \\
\hline INFL $\times$ nonempire & - & - & 0.31 & - \\
\hline EXPORTS & - & - & - & 1.24 \\
\hline LOGY & - & - & - & -1.50 \\
\hline
\end{tabular}

Notes: Dependent variable is SPREAD. Country-specific $\beta_{i}$ are not reported, $p$-values are shown in brackets and $t$-statistics are shown in parentheses. "Sargan" is the Sargan test of overidentifying restrictions, distributed $\chi^{2}$ squared. $m_{2}$ is the Arellano-Bond test that average autocovariance in residuals of order 2 is 0 , distributed asymptotically $N(0,1)$. The one-step estimator is used, and debt and inflation terms are treated as endogenous. See text for details.

Sources: See text and appendix. 
section, as suggested Bordo, Edelstein, and Rockoff (1999). A second problem concerns departures from gold in the gathering crisis of 1929-31. It is implausible that Australia, for example, could have avoided an increase in borrowing spreads in 1930 simply by somehow clinging to the gold standard and its rules. Since we therefore do not want to impute such spread increases to departures from gold per $s e$, we introduce the new dummy variable GSOFF. A third difficulty is that whereas previously we had up to 44 observations per country in the time dimension, we now have at most 7; it is therefore unwise to estimate country-specific autoregressive parameters $\rho_{i}$, so we adopt a specification with $\rho_{i}=\rho$ for all countries.

Tables 4 and 5 can be directly compared with Tables 1 and 2. Table 4 shows the interwar analysis for the full sample, 143 observations, with no additional controls. Regression 1 in Table 4 suggests that unconditionally (that is, without reference to the restoration of the prewar parity), the gold standard had at best a minimal impact on spreads (10 basis points). And even this small estimated effect is far from statistical significance. Regression 2 partitions the GS dummy to account for postwar devaluations. According to these estimates, countries returning to gold at the prewar parities gained nothing in reduced spreads (indeed the sign of GSPAR is wrong), whereas countries like France that returned after devaluing received a benefit of roughly 35 basis points that falls just shy of conventional statistical significance levels.

These findings run quite contrary to the Bordo-Edelstein-Rockoff empirical results. Echoing the conventional wisdom of interwar policymakers, they found that sticking to the prewar parity was rewarded by markets with a continued (and large) discount on borrowing costs of over 100 basis points. But countries that resumed at a devalued parity gained nothing, as their credibility was damaged. We note that in both regressions of Table 4 the variable GSOFF has a large coefficient (60-70 basis points) and is highly significant. Spreads rose sharply for primary exporters like Australia, Argentina, and Uruguay that left gold before Britain did. Were we to omit the variable GSOFF, we would find approximately a -30 basis point coefficient on GSPAR and a -50 basis point coefficient on GSDEV (see Obstfeld and Taylor 2003), but as we have argued, these seeming benefits of gold adherence would be an artefact of the harsh external conditions peripheral countries faced at the onset of the Great Depression. Consistent with that interpretation, we note that if we omit the GSOFF dummy but drop the crisis year 1931, the results move closer to those in Table $4 .^{20}$

\footnotetext{
${ }^{20}$ As we explain in the appendix, there is disagreement among scholars as to whether Uruguay could be considered to be on gold in 1928-29. We believe that the markets took the country's de
} 
Table 4: Country Risk and the Gold Standard, 1925-31

\begin{tabular}{|c|c|c|}
\hline & (1) & (2) \\
\hline Observations & 143 & 143 \\
\hline$R^{2}$ & 0.95 & 0.95 \\
\hline GS & $-0.10(0.75)$ & - \\
\hline GSPAR & - & $0.05(0.30)$ \\
\hline GSDEV & - & $-0.33(1.74)$ \\
\hline GSOFF & $0.63(3.20)$ & $0.70(3.50)$ \\
\hline ARG & $-0.08(0.14)$ & $-0.26(0.43)$ \\
\hline AUS & $-0.17(0.29)$ & $-0.31(0.53)$ \\
\hline AUT & $0.91(1.56)$ & $1.15(1.93)$ \\
\hline BEL & $0.90(1.55)$ & $1.10(1.86)$ \\
\hline BRZ & $1.79(3.08)$ & $1.98(3.37)$ \\
\hline CAN & $-0.79(1.32)$ & $-0.85(1.43)$ \\
\hline CHL & $1.14(1.94)$ & $1.39(2.31)$ \\
\hline DNK & $-1.36(2.33)$ & $-1.49(2.56)$ \\
\hline EGY & $0.07(0.12)$ & $-0.07(0.12)$ \\
\hline FIN & $0.17(0.28)$ & $0.42(0.70)$ \\
\hline FRA & $0.70(1.19)$ & $0.97(1.59)$ \\
\hline GER & $2.68(4.58)$ & $2.92(4.89)$ \\
\hline HUN & $3.71(6.34)$ & $3.95(6.62)$ \\
\hline IND & $0.88(1.51)$ & $0.76(1.30)$ \\
\hline ITA & $2.97(3.08)$ & $3.29(3.35)$ \\
\hline JPN & $0.81(1.43)$ & $0.80(1.41)$ \\
\hline NZL & $0.08(0.14)$ & $-0.05(0.09)$ \\
\hline NOR & $-0.98(1.67)$ & $-1.15(1.93)$ \\
\hline PRT & $1.76(3.08)$ & $1.75(3.09)$ \\
\hline RSA & $-0.51(0.87)$ & $-0.66(1.12)$ \\
\hline SWE & $-0.36(0.62)$ & $-0.51(0.87)$ \\
\hline TUR & $3.13(5.49)$ & $3.14(5.55)$ \\
\hline USA & $-1.38(2.36)$ & $-1.53(2.60)$ \\
\hline URU & $4.27(7.24)$ & $4.12(6.92)$ \\
\hline$\rho$ & $0.45(8.57)$ & $0.45(8.43)$ \\
\hline Mean empire & $-0.07(0.27)$ & $-0.20(0.72)$ \\
\hline Mean nonempire & $1.15(6.30)$ & $1.22(6.56)$ \\
\hline Difference (Empire effect) & $-1.23(4.49)$ & $-1.42(4.79)$ \\
\hline
\end{tabular}

Notes: Dependent variable is SPREAD. Country-specific $\beta_{i}$ are not reported; $t$-statistics are shown in parentheses. Mean empire and mean nonempire show average fixed effect for the group.

Sources: See text and appendix. 
What could possibly explain our result — a reversal of the classic ideologyaccording to which parity keepers gain nothing, and the market, if anything, rewards devaluers? The result is not so far fetched when markets try to assess which promises actually can be kept. In this respect, our findings support the theoretical conclusion of Drazen and Masson (1994) that policymakers may hurt rather than enhance their credibility through policies that appear "tough" in the short term but are too draconian to be sustained for long. These initial results are far from conclusive, of course, given the moderate statistical significance of the gold standard effect, but the question certainly warrants further research.

Our findings are so obviously at variance with the results of Bordo-EdelsteinRockoff that some explanation is needed. The contrast could be ascribed to differences in concept (use of secondary-market bond yields, mostly in London, versus new issue yields in New York) and differences in estimation method. Of these features in our empirical approach, the first, at least, seems necessary if we are to make comparisons on an equal footing with the prewar period and Bordo and Rockoff (1996). For the same reason an autoregressive correction of some sort would seem essential, although Bordo, Rockoff, and Edelstein (1999) used simple OLS. One reason for their choice, we think, was an unfortunate feature of Cleona Lewis's interwar data on New York bond issues: these were primary issues, so not every country had a bond issue every year, leading to gaps in the time series, and hence the impossibility of an AR1 correction. A more subtle difficulty, which our approach confronts, is an inherent problem of sample selection bias when using primary-issue data of Lewis's kind. Countries tend only to float bonds when they are creditworthy, so this yields a biased sample, as noted earlier. In contrast, by using secondary market data from London, we can track countries in all years, whatever their predicament.

Table 5 adds additional controls. The coefficient of GSDEV is virtually the same-roughly 35 basis points, a number smaller than our estimated reward for prewar adherence to gold — but it becomes statistically significant. In addition, GSPAR remains essentially zero while GSOFF is slightly lower but still highly significant. In contrast to the prewar results, public debt now has a statistically significant positive effect on borrowing costs. This is a second key contrast with the classical prewar gold standard. All four regressions in Table 5 indicate that

facto gold adherence at its prewar parity seriously (and indeed, the country's borrowing spreads were somewhat lower in 1928-29 than before or after). However, the only significant effect (in all our regressions) of adopting the alternative coding for Uruguay is to reduce the measured effect of GSOFF. This result is expected because a relatively small group of countries left gold before June 1931 and Uruguay suffered a large increase in its borrowing spread. 
Table 5: Country Risk and the Gold Standard, 1925-31: Additional Controls

\begin{tabular}{|c|c|c|c|c|}
\hline & (1) & (2) & (3) & (4) \\
\hline Observations & 137 & 137 & 137 & 137 \\
\hline$R^{2}$ & 0.96 & 0.96 & 0.96 & 0.96 \\
\hline$\overline{\text { GSPAR }}$ & $0.04(0.27)$ & $\overline{0.02(0.15)}$ & $\overline{0.04(0.26)}$ & $\overline{0.07(0.55)}$ \\
\hline GSDEV & $-0.37(2.21)$ & $-0.37(2.23)$ & $-0.37(2.17)$ & $-0.33(2.01)$ \\
\hline GSOFF & $0.58(3.46)$ & $0.57(3.38)$ & $0.58(3.38)$ & $0.56(3.27)$ \\
\hline DEBT & $1.41(3.33)$ & $1.23(2.64)$ & $1.38(1.52)$ & $1.31(2.94)$ \\
\hline INFL & $0.04(0.36)$ & $0.02(0.18)$ & $0.24(0.09)$ & $0.09(0.90)$ \\
\hline DEBT $\times$ periphery & - & $1.18(1.04)$ & - & - \\
\hline INFL $\times$ periphery & - & $0.08(0.30)$ & - & - \\
\hline DEBT $\times$ nonempire & - & - & $0.05(0.05)$ & - \\
\hline INFL $\times$ nonempire & - & - & $-0.21(0.08)$ & - \\
\hline EXPORTS & - & - & - & $0.15(0.13)$ \\
\hline LOGY & - & - & - & $-1.19(2.16)$ \\
\hline ARG & $-0.87(1.60)$ & $-1.29(1.93)$ & $-0.88(1.57)$ & $8.86(1.97)$ \\
\hline AUS & $-2.71(3.06)$ & $-2.39(2.50)$ & $-2.63(1.67)$ & $7.45(1.55)$ \\
\hline AUT & $0.92(1.75)$ & $0.74(1.31)$ & $0.91(1.71)$ & $10.54(2.37)$ \\
\hline BEL & $-0.12(0.19)$ & $0.03(0.04)$ & $-0.14(0.21)$ & $9.94(2.15)$ \\
\hline BRZ & $1.61(3.05)$ & $1.30(2.11)$ & $1.60(2.95)$ & $9.87(2.59)$ \\
\hline CAN & $-1.40(2.58)$ & $-1.31(2.37)$ & $-1.38(2.21)$ & $8.44(1.86)$ \\
\hline CHL & $0.84(1.54)$ & $0.43(0.64)$ & $0.83(1.47)$ & $10.00(2.34)$ \\
\hline DNK & $-1.81(3.51)$ & $-1.77(3.37)$ & $-1.82(3.46)$ & $8.27(1.78)$ \\
\hline EGY & $-0.78(1.38)$ & $-1.29(1.68)$ & $-0.75(1.05)$ & $7.05(1.95)$ \\
\hline FIN & $0.31(0.59)$ & $0.21(0.39)$ & $0.30(0.57)$ & $9.59(2.24)$ \\
\hline FRA & $-1.21(1.44)$ & $-0.92(1.03)$ & $-1.24(1.32)$ & $8.84(1.87)$ \\
\hline GER & $2.82(5.41)$ & $2.86(5.42)$ & $2.81(5.32)$ & $12.54(2.80)$ \\
\hline HUN & $3.71(7.03)$ & $3.50(6.02)$ & $3.71(6.87)$ & $12.92(3.03)$ \\
\hline IND & $0.26(0.47)$ & $-0.14(0.20)$ & $0.29(0.44)$ & $7.97(2.21)$ \\
\hline ITA & $2.46(2.68)$ & $1.82(1.64)$ & $2.44(2.59)$ & $12.14(2.66)$ \\
\hline JPN & $0.11(0.21)$ & $-0.36(0.52)$ & $0.10(0.19)$ & $9.14(2.18)$ \\
\hline NZL & $-2.48(2.73)$ & $-2.13(2.17)$ & $-2.41(1.45)$ & $7.69(1.61)$ \\
\hline NOR & $-1.64(3.01)$ & $-1.54(2.77)$ & $-1.65(2.96)$ & $7.81(1.78)$ \\
\hline PRT & $0.73(1.29)$ & $0.05(0.06)$ & $0.72(1.21)$ & $9.71(2.31)$ \\
\hline RSA & $-1.27(2.32)$ & $-1.71(2.43)$ & $-1.25(1.88)$ & $7.65(1.84)$ \\
\hline SWE & $-0.79(1.53)$ & $-0.74(1.42)$ & $-0.79(1.52)$ & $8.95(1.99)$ \\
\hline USA & $-1.79(3.47)$ & $-1.74(3.33)$ & $-1.80(3.43)$ & $8.54(1.78)$ \\
\hline URU & $3.25(5.46)$ & $2.60(2.93)$ & $3.24(5.19)$ & $12.90(2.85)$ \\
\hline$\rho$ & $0.40(8.09)$ & $0.39(7.31)$ & $0.40(7.95)$ & $0.40(7.59)$ \\
\hline Mean empire & $-1.40(3.12)$ & $-1.49(3.22)$ & $-1.36(1.66)$ & $\overline{7.71(1.83)}$ \\
\hline Mean nonempire & $0.50(1.96)$ & $0.30(0.94)$ & $0.49(1.74)$ & $10.03(2.29)$ \\
\hline Difference (Empire effect) & $-1.90(5.91)$ & $-1.80(5.34)$ & $-1.85(2.16)$ & $-2.33(6.27)$ \\
\hline
\end{tabular}

Notes and Sources: See Table 4. 
although the markets cared little about being on gold in the interwar period, they did care about public debt levels. For example, a coefficient of 1.41 on DEBT in our table (Regression 1) means that a 10 percentage point increase in a country's debt to GDP ratio would be expected to raise country risk by 14.1 basis points. Inflation is never statistically significant. Regressions 2 and 3 of Table 5 allow for the inclusion of periphery and empire interaction terms, but, based on their statistical significance, they do not seem to be justified. Regression 4 adds controls for the export ratio and level of development. Exports are incorrectly signed but statistically quite insignificant. The income coefficient is, however, statistically significant and somewhat larger than in the prewar results in Table 2. Once again, we caution that the interpretation of the LOGY variable is unclear since it could be a proxy for various institutional, economic or other factors affecting risk. Even so, in our AR1 models it appears to have a robust and fairly stable coefficient both prewar and interwar, so we again choose the final column as our preferred AR1 specification.

When compared to our earlier prewar findings based on the same specifications, these results show that the value of being on gold at the traditional parity fell to zero after the war. Based on the latter, the bottom line for the interwar period could then be summed up as: the gold standard strikes out but the Empire strikes back. Table5 suggests that the value of being in the Empire was much higher than being on gold, and much higher than it had been prior to the war. Based on the analysis of mean fixed effects, an Empire member might have expected a borrowing discount of anywhere between 180 and 230 basis points.

This finding makes intuitive sense. Prior to World War One, the long trend of globalisation in the world economy and a convergence on a set of more or less liberal economic policy principles (a kind of "London consensus") had placed economic actions at centre stage in the minds of market actors. The sudden specter of total war, the shock of political instability and revolution, the rise of belligerence in the core economies, and a general air of noncooperative policymaking could well have changed the weight given to various signals in the world bond market. Suddenly, the safe haven of Empire investments might have looked more attractive, just as the gold standard began to lose its glitter. And, more generally, this interpretation sits comfortably with the conventional wisdom that the world economy as a whole was becoming increasingly organised along regional, bilateral, or imperial lines in the interwar years, due to preferential policies in both trade and finance. For example, after the onset of war, in the 1910s and 1920s, Britain began to curtail nonempire access to the London capital market and by the 1930s the British Empire had become a heavily protected trading zone under the auspices of the Ottawa accords. 
In a further sensitivity check, Table 6 reports GMM estimates for a laggeddependent-variable model of spreads. Using the Arellano and Bond (1991) onestep dynamic panel estimator once again, we find results broadly consistent with the AR1 estimates from Tables 4 and 5, although standard errors are much higherwhich is perhaps no surprise given the shortness of the interwar panel and the loss of one cross-section due to differencing. Here, returning to the gold standard at the prewar parity appears to have yielded no reduction in spreads, but parity devaluation shows a risk reduction somewhere around 20 basis points, an effect that is economically but not statistically significant. Debt generally was punished by the markets, more harshly on the periphery and perhaps outside the Empire. Inflation appears not to matter except for column 3 where the effects are implausibly large and offsetting in empire and nonempire cases. This strange result argues against such a specification. In our preferred specification, reported in the last column, the long-run coefficient on debt is higher than in Table 5. Importantly, Tables 4 and 5 consistently show that interwar debt effects were large and positive compared to the (statistically insignificant and often wrongly signed) impacts found for the prewar period in Tables 2 and 3. Also in the GMM interwar regressions in Table 6, we find, as before, that higher income per capita reduced spreads.

To summarise, by the late 1920s the market's approach to risk pricing had changed dramatically. If markets rewarded gold adherence at all, they did so only when the adoption of gold was based upon a realistically competitive exchange rate. In addition, policymakers faced a world in which the mere word of their commitment to the gold standard was no longer good enough—now creditors also wanted to see the books.

\section{Conclusion}

In the sovereign bond market before 1914, the gold standard did indeed confer a "seal of approval," whereas macro fundamentals, measured by public debt and inflation, seem to have mattered little, if at all. Apparently adherence to gold, in and of itself, was sufficient to enhance market credibility during that era. Membership in the British Empire was neither a necessary nor sufficient condition for preferential access to London's capital market before 1914. The results accord with historians' views on the high degree of economic globalisation attained before the First World War.

For the interwar period, a return to gold after devaluation seems to have been more credible, notwithstanding the arguments that led Britain and other countries 
Table 6: Country Risk and the Gold Standard, 1925-31: GMM Estimates

\begin{tabular}{|c|c|c|c|c|}
\hline & (1) & (2) & (3) & (4) \\
\hline Observations & 132 & 132 & 132 & 132 \\
\hline Sargan & $21.56[1.00]$ & $45.61[1.00]$ & $38.67[1.00]$ & $39.14[1.00]$ \\
\hline$m_{2}$ & $0.37[0.71]$ & $0.32[0.75]$ & $0.08[0.94]$ & $0.80[0.42]$ \\
\hline SPREAD(t-1) & $0.30(2.10)$ & $0.26(1.91)$ & $0.30(2.20)$ & $0.05(0.39)$ \\
\hline GSPAR & $0.14(0.85)$ & $0.17(1.08)$ & $0.04(0.25)$ & $0.21(1.38)$ \\
\hline GSDEV & $-0.17(0.85)$ & $-0.10(0.50)$ & $-0.29(1.47)$ & $-0.17(0.93)$ \\
\hline GSOFF & $0.37(1.60)$ & $0.50(2.17)$ & $0.33(1.42)$ & $0.43(1.97)$ \\
\hline DEBT & $1.82(1.98)$ & $0.85(1.04)$ & $1.06(0.67)$ & $2.20(2.72)$ \\
\hline INFL & $0.51(0.57)$ & $0.29(0.30)$ & $5.64(1.70)$ & $-0.02(0.03)$ \\
\hline DEBT $\times$ periphery & - & $3.48(1.69)$ & - & - \\
\hline INFL $\times$ periphery & - & $-0.50(0.39)$ & - & - \\
\hline DEBT $\times$ nonempire & - & - & $1.03(0.62)$ & - \\
\hline INFL $\times$ nonempire & - & - & $-6.26(1.82)$ & - \\
\hline EXPORTS & - & - & - & $-0.07(0.05)$ \\
\hline LOGY & - & - & - & $-1.70(2.55)$ \\
\hline \multicolumn{5}{|l|}{ Long-run coefficient } \\
\hline GSPAR & 0.19 & 0.23 & 0.06 & 0.22 \\
\hline GSDEV & -0.24 & -0.13 & -0.41 & -0.18 \\
\hline GSOFF & 0.53 & 0.67 & 0.47 & 0.45 \\
\hline DEBT & 2.58 & 1.14 & 1.52 & 2.32 \\
\hline INFL & 0.72 & 0.39 & 8.06 & -0.02 \\
\hline $\mathrm{DEBT} \times$ periphery & - & 4.69 & - & - \\
\hline INFL $\times$ periphery & - & -0.67 & - & - \\
\hline DEBT $\times$ nonempire & - & - & 1.47 & - \\
\hline INFL $\times$ nonempire & - & - & -8.96 & - \\
\hline EXPORTS & - & - & - & -0.08 \\
\hline LOGY & - & - & - & -1.80 \\
\hline
\end{tabular}

Notes and Sources: See Table 3. 
to return to gold at par. Indeed, returning at par yielded essentially no benefit, and only a return after devaluation (as in the case of France) was beneficial, though not quite as beneficial as being on gold prior to World War One. Moreover, for core and periphery countries alike, high public debts were punished, suggesting that policymakers' room for maneuver had been curtailed. In the troubled interwar environment, Empire membership emerged as an important qualification for lower borrowing costs.

Both our results on the drop in spreads associated with going on gold, and on markets' differential response to public debt before and after the war, suggest that the interwar gold standard was less credible than its pre-1914 predecessor. It remains to reconcile these results fully with findings such as those of Hallwood, MacDonald, and Marsh (1996) that indicate a credible gold standard during the late 1920s, at least in the short-term bond markets. Perhaps the bond markets adopted a longer perspective under which protracted adherence to unchanging gold parities seemed less probable than short-term adherence. The question certainly deserves further research, but our findings on bond markets serve to illuminate how different the interwar global capital market was from its antecedent, the classical gold-standard regime of 1870-1914. Evidently the global convergence in the bond market prior to 1914 was replaced by quite different, disintegrative forces after 1914.

Finally, if we seek lessons from the past, our results have some implications for today's attempts to gain capital market credibility through the use of pegged exchange rates. It is clear that the post-World War One political developments that rendered interwar exchange-rate commitments less credible have not receded in the meantime. Thus, policymakers should not expect to gain market credibility even through seemingly irrevocable exchange rate commitments. Absent robust fundamentals and complementary economic and institutional reforms, efforts to forswear discretionary exchange rate changes are of questionable value. 


\section{Data Appendix}

The database covers the period 1870 to 1939 at an annual frequency. The core countries are defined as Australia, Belgium, Canada, Denmark, France, Germany, New Zealand, Norway, Sweden, and the United States. The empire countries are defined as Australia, Canada, India, New Zealand, and South Africa. The peripheral countries are defined as Argentina, Austria (and Austria-Hungary), Brazil, Chile, Egypt, Finland, Greece, Hungary, India, Italy, Japan, Mexico, Portugal, South Africa, Spain, Turkey, and Uruguay. The base country for yields is the United Kingdom. Before World War One, Turkey refers to the Ottoman Empire and Austria denotes Austria-Hungary (and there are no independent data for Hungary). There are missing data for most variables.

\section{Exchange rate}

Exchange rate versus the U.S. dollar from Bordo and Schwartz (1997) and Global Financial Data (GFD), except as follows.

Argentina: from della Paolera and Taylor (2001).

Chile: 1870-79 annual average from Braun et al. (2000).

\section{Gold standard}

The gold standard dummy variable is equal to one when a country is on the gold standard, otherwise zero. The gold standard parity dummy (GSPAR) is equal to one when a country rejoins gold after 1914 at parity that is the same as the previous one. The gold standard devalued dummy (GSDEV) is equal to one when a country rejoins gold at parity after 1914 that is devalued relative to the previous one. (There are cases where countries rejoined gold at a revalued parity, such as India in the 1920s, but these are not coded in any special way.)

Prewar coding. Data are from Meissner (2002), available for all countries in all years, except as follows:

Argentina: On gold for 1899-1902 (see della Paolera and Taylor, 2001).

Belgium: Off gold in 1926 (see Eichengreen, 1992, p. 168 et seq.).

India: Off gold 1870-97 following Hawtrey (1947) and Eichengreen (1992) and based on exchange rate volatility.

Uruguay: On gold for 1885-99 (Luis Bértola, private communication; we have no exchange rate data for Uruguay prior to 1885 to verify adherence).

Interwar coding. As discussed in the text, the interwar coding of gold standard adherence involves greater subjective judgment than for the prewar period. In addition, because we use June observations for the interwar period, annual summaries of adherence are patently insufficient; we must know the month, and in some cases the day, of entry to or 
exit from the gold standard. We do not attempt to distinguish among various degrees of adherence, that is, gold bullion standard, gold coin standard, or gold exchange standard. In most cases, however, we demand not only that a currency be stable de facto in terms of gold, but that it be convertible de jure, with the free import and export of gold allowed by the issuing country. Countries on gold are considered to leave the gold standard if they prohibit cross-border gold flows or impose other exchange controls, even if they do not simultaneously devalue or float their currencies.

The dates that we use for the interwar transitions to and from the gold standard are as follows:

\begin{tabular}{lll}
\hline \hline & On Gold & Off Gold \\
\hline Argentina & Aug. 1927 & Dec. 1929 \\
Australia & April 1925 & Jan. 1930 \\
Austria & March 1925 & Oct. 1931 \\
Belgium & Oct. 24, 1926 & March 1935 \\
Brazil & Dec. 18, 1926 & Dec. 7, 1929 \\
Canada & July 1, 1926 & Jan. 1929 \\
Chile & Jan. 11, 1926 & July 1931 \\
Denmark & Jan. 1927 & Sept. 1931 \\
Egypt & April 1925 & Sept. 1931 \\
Finland & Dec. 31, 1925 & Oct. 1931 \\
France & June 25, 1928 & Sept. 26, 1936 \\
Germany & Oct. 1924 & July 1931 \\
Hungary & April 1925 & Aug. 1931 \\
India & March 1927 & Sept. 1931 \\
Italy & Feb. 26, 1928 & Dec. 1934 \\
Japan & Jan. 1930 & Dec. 1931 \\
New Zealand & April 1925 & April 1930 \\
Norway & May 1928 & Sept. 1931 \\
Portugal & July 1, 1931 & Oct. 1931 \\
South Africa & April 1925 & Jan. 1933 \\
Sweden & March 1924 & Sept. 1931 \\
Uruguay & Jan. 1928 & Dec. 1929 \\
United States & June 1919 & April 1933 \\
\hline \hline
\end{tabular}

Our sources are as follows:

Argentina: Brown (1940, pp. 401 and 893).

Australia: Eichengreen (1992, pp. 192 and 235).

Austria: Federal Reserve Bulletin, August 1928, p. 562 and Brown (1940, p. 926).

Belgium: Brown (1940, p. 426) and Yeager (1976, p. 359). 
Brazil: The "on gold" date is for de facto adoption of a gold peg through a currency reform law. See Fritsch (1988, p. 122). The departure date, from Fritsch (p. 156), is the day on which the Banco do Brasil withdrew foreign exchange support. Fritsch (p. 122-23) explains that the currency reform law provided for a phased transition from de facto to de jure convertibility, with the date of de jure credibility left open and dependent on the level of government gold holdings. Brazil left gold, however, before the transition was completed. Because Brazil's adherence to gold was codified in legislation, we use the date of passage as our "on gold" date.

Canada: Shearer and Clark (1984, pp. 282 and 297) and Brown (1940, pp. 396 and 906).

Chile: Brown (1940, pp. 396 and 912).

Denmark: Lester (1939, p. 200) and Brown (1940, p. 1075).

Egypt: The "on gold" date is inferred from the exchange rate's behaviour against sterling, as reported in GFD, and Britain's date of adherence to gold. The "off gold" date is from Brown (1940, p. 1075).

Finland: Brown (1940, pp. 396 and 1075).

France: Yeager (1976, pp. 329 and 362). We treat France as being off gold during June 1928.

Germany: Brown (1940, p. 469) and Yeager (1976, p. 340).

Hungary: Eichengreen (1992, p. 192) and Brown (1940, p. 1198).

India: Brown (1940, pp. 839 and 1075).

Italy: Brown (1940, p. 951), Kindleberger (1986, p. 162), and Yeager (1976, p. 360). Japan: Yeager (1976, p. 330) and Brown (1940, p. 1075).

New Zealand: Yeager (1976, p. 323, n. 30) and Brown (1940, p. 1075).

Norway: Lester (1939, p. 213) and Brown (1940, p. 1075).

Portugal: The Economist, June 6, 1931, and Brown (1940, p. 1075).

South Africa: Yeager (1976, p. 323, n. 30) and Brown (1940, p. 1075).

Sweden: Yeager (1976, p. 323, n. 30) and Lester (1939, p. 229).

Uruguay: De facto adoption inferred from Officer (2001) and the exchange rate's behaviour, as reported in GFD. December 1929 date for gold abandonment from Brown (1940, p. 893) and Kindleberger (1986, p. 89), though the currency was allowed to depreciate below par in April 1929. According to a private communication from Luis Bértola, Uruguay never returned to gold after August 1914; instead it simply pegged the exchange rate. Brown's account suggests, however, that contemporaries viewed Uruguay, like its larger neighbor Argentina, as being effectively on gold, and we take that view in our coding. In the text we discuss how our results change if Uruguay is considered to be off gold throughout 1925-31.

United States: Brown (1940, pp. 207-8 and 1075). 


\section{Yield}

See discussion in the text. Yield on long-term gold or sterling government bonds (at least ten years) measured typically by the coupon-price ratio, with definitions and sources as follows, based on London quotations where available.

Argentina: 1884-1913 from della Paolera (1988). 1914-34 from Nakamura and Zarazaga (2002).

Australia: From GFD. The bonds quoted are the N.S.W. 5\% Terminable 1874/1902 (1870-87); N.S.W. 4\% funded Stock 1912 option (1887-1900); all N.S.W. and Commonwealth issues maturing in more than six months (1901-15); 5.25\%, 5.5\% and 5\% bonds (1920-40). Australian prices are used from 1875 to 1887, and from 1894 to 1915.

Austria: From GFD. For pre-WWI Austria-Hungary the bonds quoted are the Gold 5s (1879-1915); for interwar Austria the bonds quoted are the 6s of 1923-43 (1923-32) quoted in London and payable in sterling.

Belgium: No prewar yields (except in domestic currency). 1925-33 from the Wall Street Journal. The bond is the 7\% of 1955 quoted in New York.

Brazil: From GFD. The bonds quoted are the 5s (1870-86); the Gold 4.5s (1887-99); the 4.5s of 1883 (1900-13); the 5s of 1912 (1914); and the Funded 5s of 1914 (1915-37).

Canada: From GFD. The bonds quoted are the 5s (1860-73); the 4s of 1910 and 1935 (1874-1924); and the Gold 5s of 1952, the latter quoted in New York (1925-40).

Chile: 1870-1918 From GFD. The bonds quoted are the 6s (1870-74); the 5s (187586); the 4.5s (1887-1918. 1919-33 from Investor's Monthly Manual, The Times, and The Economist. The $4.5 \%$ Bond of 1886 is used between 1919 and 1930. Thereafter the 6\% Loan of 1929-62. Both debt instruments were issued in London and were payable in sterling.

Denmark: 1919-33 from Investor's Monthly Manual, The Times, and The Economist. The bond quoted is the 3\% Sterling Loan of 1897-1948. This bond was issued by the Danish government in London and was payable in Sterling.

Egypt: From GFD. The bonds quoted are the Unified Stock (1870-1931), which had a variable coupon rate of $7 \%$ through March 1877, 6\% through June 1882, and 4\% from July 1883 until 1931.

Finland: 1991-1917 from GFD. 1919-33 from Investor's Monthly Manual, The Times, and The Economist. The bond quoted is the 6\% Sterling Loan of 1923-63. This was issued in London and its associated payments were made in sterling pounds.

France: No prewar yields (except in domestic currency). 1925-33 from the Wall Street Journal. The bond is the 7\% of 1949 quoted in New York.

Germany: No prewar yields (except in domestic currency). 1925-38 from GFD. The bond quoted is the 7\% Dawes Loan of 1924.

Greece: From GFD. The bonds quoted are the 5s of 1824/1879 (1870-86) and the Monopoly 4s (1887-1924). 
Hungary: Not included before WWI; see Austria. From GFD. The bond quoted is the 7.5\% Dawes Loan of 1924 (1924-39).

India: From GFD. The bonds quoted are the 5s of 1880 (1870-73); 4s of 1888 (1874 80); 3.5s of 1931 (1881-1940).

Italy: 1919-30 from Investor's Monthly Manual and The Times. The bond quoted is the Maremmana Railway Bond issued in London and payable in sterling pounds.

Japan: From GFD. The bonds quoted are the 9s (1870-72); the 7s (1873-97) converted to 5s (1898-99); the Sterling 4s (1900-23); and the 6s of 1924 (1924-38).

Mexico: From GFD. The bonds quoted are the 3s (1870-88); the 6s (1889-99); and the External Gold 5s of 1899 (1900-32).

New Zealand: From GFD. The bonds quoted are the 5s (1870-80); 4s (1881-94); 3s of 1945 (1895-1914); no data available from 1914 to 1924 ; 3.5s of 1940 (1925-27); 5s of 1946 (1928-32); 4s of 1952-55 (1933-36); and 3.5s of 1953-57 (1937-40).

Norway: 1870-1918 from GFD. The bonds quoted are the 4.5s, (1876-80), 4s (188186), 3.5s (1887-92) and 3s (1893-1918). 1921-31 from Investor's Monthly Manual, The Times, and The Economist. The bond quoted is the 6\% Loan of 1921. The bond was issued in London and payable in sterling pounds.

Portugal: From GFD. The bonds quoted are the consols, which had a variable coupon rate of 3\% through October 1895, $1 \%$ from November 1895 through 1902, and 3\% thereafter; no data for 1903, 1920-21, and 1928-30. Data are fourth quarter for 1931-32. June 1929 and 1930 observations from Investor's Monthly Manual and The Times, coupon-price ratio. In July 1924 the Portuguese government unilaterally decided to pay all its foreign currency debt in escudos except to foreign holders of its debt.

South Africa: From GFD. The bonds quoted are the Cape Colony 4.5s and 4s (18841913); Union of South Africa 4s and 4.5s (1914-21); and the Union 5\% Inscribed Debt (1922-40).

Spain: From GFD. The bonds quoted are the 3s (1870-80) converted into 1s (1881), to $4 \mathrm{~s}$ (1882-1913). Part of the $4 \%$ perpetual exterior debt of 1882 was payable in foreign currency but only at a fixed exchange rate as written in the bond. This deal was only available to non-Spaniards. After 1913 we have no data, as all bond quotes are in domestic currency.

Sweden: 1919-33 from Investor's Monthly Manual, The Times, and The Economist. The bond quoted is the $3.5 \%$ loan of 1908 . This bond was issued by the Swedish government in London and was payable in Sterling. The corresponding price is quoted in the Investor's Monthly Manual (1919-29) and The Economist (1930-33).

Turkey: 1870-1918 from GFD. The bonds quoted are the 6s of 1854 (1870-76); the 4.25\% External Tribute Bonds (1877-1913); and the Unified 4\% Bonds (1914-18). 191933 from Investor's Monthly Manual, The Times, and The Economist. The bond quoted is the Government 4\% Unified Debt of 1903-1962. This bond was issued in London and its payments were payable in sterling pounds. 
United Kingdom: From GFD. The bond quoted is the consol.

United States: 1870-1914 the Calomiris gold rate from Bordo and Rockoff (1996). 1914-39 from GFD. The bonds quoted are the 4s of 1925 (1915-1916); the 4\% Liberty Bonds (1917-18); and the Federal Reserve Board's 10-15 year Treasury Bond index (1919-39).

Uruguay: 1870-1918 from GFD. The bonds quoted yielded 6\% through 1884, 5\% from 1885 through February 1893, and 3.5\% thereafter. 1919-29 from Investor's Monthly Manual, The Times, and The Economist. The bond quoted is the Government 5\% Gold Bond of 1914 until 1922 and then the 5\% External Loan 1919. This debt instrument was issued in London and the associated payments were made in sterling pounds.

\section{Exports}

Exports in U.S. dollars from the collected volumes of Mitchell $(1992,1993,1995)$ as collated by Estevadeordal, Frantz, and Taylor (2003). Converted to local currency using the exchange rate.

\section{Public debt}

Total central government debt, unless otherwise stated. From Bordo and Jonung (1996) for the years 1870-1913, and from United Nations (1948) for 1914-39, supplemented as follows.

Argentina: 1884-1913 from della Paolera (1988).

Australia: from Barnard (1987).

Austria: Austria-Hungary 1880-1912 from series provided by Niall Ferguson based on data collected by Marc Flandreau (unpublished).

Brazil: 1880-1910 consolidated (federal state and municipal) foreign debt in pounds sterling from IBGE (1990) and domestic debt in contos from Levy (1995).

Chile: 1870-1913 from Mamalakis (1978-89, vol. 6, p. 493, Table 8.62) thence from United Nations, with appropriate conversions of some series from (gold) pesos of 6 pence (the interwar parity) to current pesos via the exchange rate series as above from Braun et al. (2000).

Egypt: 1876-1913 from data provided by Niall Ferguson based on Crouchley (1938). Interwar UN data is foreign debt only 1924-29, but the domestic debt (included after 1928) was negligible.

Hungary: Interwar UN data is foreign plus domestic long-term debt only 1924-28, but the domestic short-term debt was negligible.

India: From Reserve Bank of India (1954).

New Zealand: From Lloyd Prichard (1970).

Portugal: From Valério (2001, Table 9.7). 
Spain: From Barciela and Carreras (1989, Table 10.31).

Turkey: 1925-28 from Tezel (1982).

Uruguay: Unpublished data from Reto Bertoni, kindly provided by Luis Bértola, and based on the official data from Anuarios estadísticos.

\section{Nominal GDP}

From the collected volumes of Mitchell (1992, 1993, 1995), collated or augmented by Bordo and Schwartz (1997) and GFD, supplemented as follows.

Argentina: 1884-1939 from della Paolera and Ortiz (1995).

Austria: Austria-Hungary 1880-1913 data provided by Niall Ferguson based on data collected by Marc Flandreau (unpublished).

Belgium: Interpolations for missing data in 1925-26, 1928-29, and 1931-33.

Egypt: From Yousef (2002).

France: From Jones and Obstfeld (2001).

Greece: Missing data 1924-26 from backcast of 1927-29 trend.

Hungary: 1924 based on 1925-26 trends in real GDP per capita and inflation, as below. India: From Goldsmith (1983).

New Zealand: 1870-1933 from Hawke (1975); 1934-39 from Lineham (1968).

Portugal: From Nunes, Mata, and Valério (1989).

Spain: From Prados (2002).

Uruguay: 1870-1936 real GDP from Bértola (1998), inflated using a price deflator, and then rescaled and linked to the series from Bertino and Tajam (2000).

\section{Real GDP per capita}

From Maddison (1995), supplemented as follows, and interpolated as necessary.

Argentina: 1884-1939 using GDP from della Paolera and Ortiz (1995) and population Vázquez Présedo (1971-76) scaled to the Maddison 1913 benchmark.

Austria: Austria-Hungary 1880-1913 from Schulze (2000) scaled to the Maddison 1913 benchmark, using population weights for Austria and Hungary.

Belgium: 1870-1913 estimate constructed from real GDP index and consumer price index, scaled to the Maddison 1913 benchmark.

Chile: From Braun et al. (2000), scaled to the Maddison (1995) 1913 benchmark.

Egypt: From Yousef (2002), scaled to the Maddison (2001) 1913 benchmark.

Portugal: From Nunes, Mata, and Valério (1989), scaled to the Maddison (2001) 1913 benchmark.

Uruguay: Real GDP from same sources as nominal GDP; population from Maddison (2001) for 1870 and Mitchell (1993) for 1900-39; scaled to the Maddison (2001) 1913 benchmark. 


\section{Inflation}

Calculated as the rate of change of the consumer price index. From Bordo and Schwartz (1997) and GFD, supplemented as follows.

Argentina: 1870-79 from Irigoin (2000); 1879-84 from Cortés Conde (1989); and 1884-1939 from della Paolera and Ortiz (1995).

Austria: Austria-Hungary 1880-1913 an implicit deflator of GDP, based on nominal GDP as above and real GDP from Schulze (2000).

Brazil: Use implicit GDP deflator.

Chile: From Braun et al. (2000).

Egypt: Use an implicit deflator of GDP, based on nominal GDP as above, and real GDP from Yousef (2002).

India: From Goldsmith (1983).

New Zealand: 1870-1914 use an implicit deflator of GDP, based on nominal GDP as above, and real GDP from Maddison (1995).

Portugal: From Nunes, Mata, and Valério (1989).

Uruguay: Use an implicit deflator of GDP, from same sources as nominal GDP

\section{Government deficit as a fraction of GDP}

From Bordo and Schwartz (1997), supplemented as follows.

Australia: 1871-79 deficit calculated as change in public debt as above. Nominal GDP as above.

Austria: Austria-Hungary 1881-1912 deficit data provided by Niall Ferguson based on data collected by Marc Flandreau (unpublished). Austrian interwar deficit calculated as change in public debt as above. Nominal GDP as above.

Belgium: Deficit calculated as change in public debt as above. Nominal GDP as above.

Chile: From Braun et al. (2000).

Egypt: Deficit calculated as change in public debt as above. Nominal GDP as above.

Hungary: Interwar deficit calculated as change in public debt as above. Nominal GDP as above.

India: Deficit from Reserve Bank of India (1954). Nominal GDP as above.

New Zealand: 1890-1939 deficit from Lloyd Prichard (1970). Nominal GDP as above. Mexico: Deficit calculated as change in public debt as above. Nominal GDP as above. Portugal: From Valério (2001, Table 9.3). Nominal GDP as above.

South Africa: Deficit calculated as change in public debt as above. Nominal GDP as above.

Spain: From Barciela and Carreras (1989, Table 10.25). Nominal GDP as above. 


\section{References}

Arellano, M., and Bond, S. R. (1991). 'Some tests of specification for panel data: Monte Carlo evidence and an application to employment equations.' Review of Economic Studies, vol. 58, pp. 277-97.

Barciela López, C. and Carreras, A. (1989). Estadísticas históricas de España: siglos $X I X-X X$. Madrid: Fundación Banco Exterior.

Barnard, A. (1987). 'Government finance.' In Australians: Historical Statistics (W. Vamplew, ed.). Broadway, New South Wales: Fairfax, Syme \& Weldon.

Barrett, D. C. (1931). The Greenbacks and Resumption of Specie Payments, 1862-1879. Cambridge, Mass.: Harvard University Press.

Bertino, M., and Tajam, H. (2002). 'El PBI de Uruguay.' Instituto de Economía, Facultad de Ciencias Económicas y de Administración, Universidad de la República, Montevideo, Uruguay. http://www.iecon.ccee.edu.uy/histo/PBIindice.htm.

Bordo, M. D., Edelstein, M., and Rockoff, H. (1999). 'Was adherence to the gold standard a "good housekeeping seal of approval" during the interwar period?' National Bureau of Economic Research no. 7186, Working Paper Series (June).

Bordo, M. D., and Jonung, L. (1996). 'Monetary regimes, inflation, and monetary reform: An essay in honor of Axel Leijonhufvud.' In Inflation, Institutions, and Information: Essays in Honor of Axel Leijonhufvud (D. Vaz and K. Velupillai, eds.). London: Macmillan.

Bordo, M. D., and Kydland, F. E. (1995). 'The gold standard as a rule: An essay in exploration.' Explorations in Economic History, vol. 32, pp. 423-64.

Bordo, M. D., Meissner, C. M., and Redish, A. (2002). 'How “original sin” was overcome: The evolution of external debt denominated in domestic currencies in the United States and the British Dominions, 1800-2000.' Rutgers University (June). Photocopy.

Bordo, M. D., and Rockoff, H. (1996). 'The gold standard as a "good housekeeping seal of approval".' Journal of Economic History, vol. 56, pp. 389-428.

Bordo, M. D., and Schwartz, A. J. (1997). 'Monetary policy regimes and economic performance: The historical record.' Working Paper Series no. 6201, National Bureau of Economic Research (September).

Braun, J., Braun, M., Briones, I., Díaz, J., Lüders, R., and Wagner, G. (2000). 'Economía chilena 1810-1995: estadísticas históricas.' Documento de Trabajo no. 187, Pontificia Universidad Católica de Chile, Instituto de Economia (Enero).

Brown, W. A., Jr. (1940). The International Gold Standard Reinterpreted 1914-1934. New York: National Bureau of Economic Research.

Cook, L. D. (2002). 'Did the classical gold standard reduce the price of capital for Russia?' Center for International Development, Harvard University (February). Photocopy.

Crouchley, A. E. (1938). The Economic Development of Modern Egypt. London: Longmans Green. 
Davis, L. E., and Gallman, R. E. (2001). Evolving Financial Markets and International Capital Flows: Britain, the Americas, and Australia, 1865-1914. Cambridge: Cambridge University Press.

Davis, L. E., and Huttenback, R. A. (1986). Mammon and the Pursuit of Empire: The Political Economy of British Imperialism. Cambridge: Cambridge University Press.

della Paolera, G. (1988). 'How the Argentine economy performed during the international gold standard: A reexamination.' Ph. D. dissertation, University of Chicago.

della Paolera, G., and Ortiz, J. (1995). 'Dinero, intermediación financiera y nivel de actividad en 110 años de historia económica argentina.' Documentos de Trabajo no. 36, Universidad Torcuato Di Tella (December).

della Paolera, G., and Taylor, A. M. (2001). Straining at the Anchor: The Argentine Currency Board and the Search for Macroeconomic Stability, 1880-1935. Chicago: University of Chicago Press.

Drazen, A., and Masson, P. R. (1994). 'Credibility of policies versus credibility of policymakers.' Quarterly Journal of Economics, vol. 109, pp. 735-54.

Edelstein, M. (1981). 'Foreign investment and empire 1860-1914.' In The Economic History of Britain Since 1700, vol. 2, (R. Floud and D. McCloskey, eds.). Cambridge: Cambridge University Press.

Eichengreen, B. J. (1992). Golden Fetters: The Gold Standard and the Great Depression, 1919-1939. Oxford: Oxford University Press.

Eichengreen, B. J. (1996). Globalizing Capital: A History of the International Monetary System. Princeton, N.J.: Princeton University Press.

Estevadeordal, A., Frantz, B., and Taylor, A. M. (2003). 'The rise and fall of world trade, 1870-1939.' Quarterly Journal of Economics, vol. 118. Forthcoming.

Ferguson, N. (2001). The Cash Nexus: Money and Power in the Modern World, 17002000. New York: Basic Books.

Ferguson, N. (2002). 'Globalization with gunboats: The costs and benefits of the British Empire revisited.' Jesus College, Oxford (April). Photocopy.

Flandreau, M., Cacheux, J. L., and Zumer, F. (1998). 'Stability without a pact? Lessons from the European gold standard, 1880-1914.' Economic Policy, vol. 26, pp. 115-62.

Flandreau, M., and Sussman, N. (2002). 'Old sins: Exchange clauses and European foreign lending in the 19th century.' Institut d'Études Politiques, Paris (July). Photocopy.

Fratianni, M., and Spinelli, F. (1984). 'Italy in the gold standard period, 1861-1914.' In A Retrospective on the Classical Gold Standard, 1821-1931 (M. D. Bordo and A. J. Schwartz, eds.). Chicago: University of Chicago Press.

Fritsch, W. (1988). External Constraints on Economic Policy in Brazil, 1889-1930. Pittsburgh, Pa.: University of Pittsburgh Press.

Goldsmith, R. W. (1983). The Financial Development of India, 1860-1977. New Haven, Conn.: Yale University Press.

Hallwood, C. P., MacDonald, R., and Marsh, I. W. (1996). 'Credibility and fundamentals: 
Were the classical and interwar gold standards well-behaved target zones?' In Modern Perspectives on the Gold Standard (T. Bayoumi, B. J. Eichengreen and M. P. Taylor, eds.). Cambridge: Cambridge University Press.

Hawke, G. R. (1975). 'Income estimation from monetary data: further explorations.' Review of Income and Wealth, vol. 21, pp. 301-07.

Hawtrey, R. G. (1947). The Gold Standard in Theory and Practice, 5th ed. London: Longmans Green.

IBGE (Fundação Instituto Brasileiro de Geografia e Estatística) (1990). Estatísticas históricas do Brasil: séries econômicas, demográficas e sociais de 1550 a 1988. Rio de Janeiro: IBGE.

Jones, M. T., and Obstfeld, M. (2001). 'Saving, investment, and gold: A reassessment of historical current account data.' In Money, Capital Mobility, and Trade: Essays in Honor of Robert Mundell (G. A. Calvo, R. Dornbusch, and M. Obstfeld, eds.). Cambridge, Mass.: MIT Press.

Kindleberger, C. P. (1986). The World in Depression, 1929-1939. Revised and enlarged edition. Berkeley and Los Angeles: University of California Press.

Lester, R. A. (1939). Monetary Experiments: Early American and Recent Scandinavian. Princeton: Princeton University Press.

Levy, M. B. (1995). 'The Brazilian public debt: Domestic and foreign, 1824-1913.' In The Public Debt in Latin America in Historical Perspective (R. Liehr, ed.). Frankfurt am Main: Vervuert.

Lewis, C. (1938). America's Stake in International Investments. Washington, D.C.,: The Brookings Institution.

Lineham, B. T. (1968). 'New Zealand's gross domestic product, 1918-1938.' New Zealand Economic Papers, vol. 2, pp. 15-26.

Lloyd Prichard, M. F. (1970). An Economic History of New Zealand to 1939. Auckland: Collins.

Macaulay, F. R. (1938). The Movements of Interest Rates, Bond Yields and Stock Prices in the United States since 1856. New York: National Bureau of Economic Research.

Maddison, A. (1995). Monitoring the World Economy. Paris: OECD.

Maddison, A. (2001). The World Economy: A Millennial Perspective. Paris: OECD.

Mamalakis, M. J. (1978-89). Historical Statistics of Chile, 6 vols. Westport, Conn.: Greenwood Press.

Martín Aceña, P. (2000). 'The Spanish monetary experience, 1848-1914.' In Monetary Standards in the Periphery: Paper, Silver, and Gold, 1854-1933 (P. Martín Aceña and J. Reis, eds.). New York: St. Martin's Press.

Matsukata, M. (1899). Report on the Adoption of the Gold Standard in Japan. Tokyo: Government Press.

Meissner, C. M. (2002). 'A new world order: Explaining the emergence of the classical gold standard.' National Bureau of Economic Research no. 9233, Working Paper 
Series (October).

Mitchell, B. R. (1992). International Historical Statistics: Europe, 1750-1988. New York: Stockton Press.

Mitchell, B. R. (1993). International Historical Statistics: The Americas, 1750-1988. New York: Stockton Press.

Mitchell, B. R. (1995). International Historical Statistics: Africa, Asia \& Oceania, 17501988. New York: Stockton Press.

Mitchell, W. C. (1908). Gold, Prices, and Wages under the Greenback Standard. Berkeley: The University Press.

Nakamura, L. I., and Zarazaga, C. E. J. M. (2003). 'Banking and finance, 1900-35.' In Argentina: Essays in the New Economic History (G. della Paolera and A. M. Taylor, eds.). Cambridge: Cambridge University Press. Forthcoming.

Nunes, A. B., Mata, E., and Valério, N. (1989). 'Portuguese economic growth 1833-1985.' Journal of European Economic History, vol. 18, pp. 291-330.

Obstfeld, M., and Taylor, A. M. (2003). 'Globalization and capital markets.' In Globalization in Historical Perspective (M. D. Bordo, A. M. Taylor, and J. G. Williamson, eds.). Chicago: University of Chicago Press.

Officer, L. H. (2001). 'Gold standard.' In EH.Net Encyclopedia (R. Whaples, ed.). October 1, 2001 URL http://www.eh.net/encyclopedia/contents/officer/gold.standard.php.

Polanyi, K. (1944). The Great Transformation. New York: Rinehart.

Reserve Bank of India (1954). Banking and Monetary Statistics of India. Bombay: Reserve Bank of India.

Rousseau, P. L., and Sylla, R. E. (2003). 'Financial systems, economic growth, and globalization.' In Globalization in Historical Perspective (M. D. Bordo, A. M. Taylor and J. G. Williamson, eds.). Chicago: University of Chicago Press.

Sargent, T. J. (1993). 'Stopping moderate inflations: The methods of Poincaré and Thatcher.' In Rational Expectations and Inflation. Second edition. New York: HarperCollins.

Shearer, R. A., and Clark, C. (1984). 'Canada and the interwar gold standard, 1920-35: Monetary policy without a central bank.' In A Retrospective on the Classical Gold Standard, 1821-1931 (M. D. Bordo and A. J. Schwartz, eds.). Chicago: University of Chicago Press.

Smith, G. W., and Smith, R. T. (1997). 'Greenback-gold returns and expectations of resumption, 1862-1879.' Journal of Economic History, vol. 57, pp. 697-713.

Temin, P. (1989). Lessons from the Great Depression. Cambridge, Mass.: MIT Press.

Tezel, Y. S. (1986). Cumhuriyet döneminin ıktisadi tarihi, 1923-1950, 2 ed. Ankara: Yurt Yayınları.

United Nations (1948). Public Debt, 1914-1946. Lake Success, N.Y.: United Nations.

Valério, N., ed. (2001). Estatisticas históricas portuguesas. Lisbon: Instituto Nacional de Estatística. 
Vázquez-Presedo, V. (1971-76). Estadísticas historicas argentinas. 2 vols. Buenos Aires: Ediciones Macchi.

Yeager, L. B. (1976). International Monetary Relations: Theory, History, and Policy. Second edition. New York: Harper \& Row.

Yousef, T. 'Egypt's growth performance under economic liberalism, 1885-1945: A reassessment using new GDP estimates.' Review of Income and Wealth. Forthcoming. 